\title{
Consequences of surface coatings and
} soil ageing on the toxicity of cadmium telluride quantum dots to the earthworm

\section{Eisenia fetida}

\section{Tatsi, K}

http://hdl.handle.net/10026.1/16479

10.1016/j.ecoenv.2020.110813

Ecotoxicology and Environmental Safety

Elsevier BV

All content in PEARL is protected by copyright law. Author manuscripts are made available in accordance with publisher policies. Please cite only the published version using the details provided on the item record or document. In the absence of an open licence (e.g. Creative Commons), permissions for further reuse of content should be sought from the publisher or author. 
2

3

6

7

8

19

20 6 8

\section{Consequences of surface coatings and soil ageing on the toxicity of cadmium} telluride quantum dots to the earthworm Eisenia fetida

Kristi Tatsi ${ }^{1}$, Thomas Hutchinson ${ }^{2}$ and Richard D. Handy ${ }^{1,3}$. ${ }^{1}$ School of Biological Sciences, Plymouth University, Drake Circus, Plymouth, PL4 8AA, UK. ${ }^{2}$ School of Environmental Sciences, Plymouth University, Drake Circus, Plymouth, PL4 8AA, UK. ${ }^{3}$ Visiting Professor, Department of Nutrition, Cihan University, Kurdistan Region, Iraq.

*To whom correspondence should be addressed. Email: r.handy@plymouth.ac.uk 17 19

Keywords: nanoparticles, toxic metals, bioaccumulation potential, growth, survival, 1 reproductive success 


\section{Abstract}

The bioaccumulation potential and toxic effects of engineered nanomaterials (ENMs) on earthworms are poorly understood and there are concerns that the hazards will change with the type of coating and soil ageing. Two studies were conducted following OECD TG 222 with minor modifications and additional endpoints to assess the effects of CdTe QDs with different coatings on earthworms (Eisenia fetida); and to determine whether bioaccumulation or toxicity changed after soil ageing. Earthworms were exposed to carboxylate $(\mathrm{COOH})$, ammonium $\left(\mathrm{NH}_{4}^{+}\right)$, or polyethylene glycol (PEG) coated CdTe QDs, or a micron scale (bulk) CdTe material, at nominal concentrations of 50, 500 and $2000 \mathrm{mg} \mathrm{CdTe} \mathrm{QD} \mathrm{kg}^{-1}$ dry weight (dw) for 28 days in Lufa 2.2 soil. The endpoints included survival, body weight, reproduction, metal accumulation, and markers of oxidative or ionoregulatory stress. In the fresh soil study, earthworms accumulated similar amounts of $\mathrm{Cd}$ and $\mathrm{Te}$ in the CdTe-bulk exposures, while the accumulation of Cd was higher than Te during the exposures to CdTe QDs. However, neither the total $\mathrm{Cd}$ nor Te concentrations in the earthworms were easily explained by the extractable metal fractions in the soil or particle dissolution, indicating other particle metrics altered bioavailability. There were on effects on survival, but some retardation of growth was observed at the higher doses. Inhibition of $\mathrm{Na}^{+} \mathrm{K}^{+}-$ATPase activity with disturbances to tissue electrolytes, as well as tissue $\mathrm{Cu}$ and $\mathrm{Mn}$ were observed, but without depletion of total glutathione in the fresh soil experiment. Additionally, juvenile production was the most sensitive endpoint, with estimated nominal $\mathrm{EC}_{50}$ of $>\mathbf{2 0 0 0}$, 108, 65, 96 mg CdTe kg-1 for bulk, PEG-, $\mathrm{COOH}$ - and $\mathrm{NH}_{4}{ }^{+}$-coated CdTe QDs, respectively. In the aged soil study, the accumulation of $\mathrm{Cd}$ and Te was higher than in the fresh soil study in all CdTe QD exposures. Survival of the adult worms was reduced in the top $\mathrm{CdTe}-\mathrm{COOH}$ and $-\mathrm{NH}_{4}{ }^{+} \mathrm{QD}$ exposures by $55 \pm 5$ and $60 \pm 25 \%$, respectively; and with decreases in growth. The nominal $\mathrm{EC}_{50}$ values for juvenile production in the aged soil were $165,88,78$ and $63 \mathrm{mg} \mathrm{CdTe} \mathrm{kg-1}^{-1}$ for bulk, PEG-, $\mathrm{COOH}$ - and $\mathrm{NH}_{4}^{+}$-coated CdTe QDs, respectively. In conclusion, exposure to nanoscale CdTe QDs, regardless of coating, caused more severe toxic effects that the CdTe bulk material and the toxicity increased after soil ageing. There was a coatingmediated effect in some cases that was not explained by the coating itself, but due to subsequent differences in the metal content and behaviour of the materials. 


\section{Introduction}

Quantum dot (QD) technology is a growing market within the nanotechnology industry. The applications include bio-imaging and medical diagnostics (Kairdolf et al., 2013), light-emitting diode (LED) technologies (Hardman, 2005), and photovoltaics that offer alternative energy solutions (Sinha et al., 2012). Inevitably, the manufacture of QDs and their use in industrial processing or products will likely cause some releases to the environment, as with other engineered nanomaterials [ENMS, (Lead et al., 2018)]. The disposal of QDs in electronics and the subsequent burning of ewaste by developing countries is a particular concern for metal releases from CdTe QDs (Luo et al., 2011). Once in the environment, CdTe QDs may also slowly degrade and release their hazardous dissolved metals (Navarro et al., 2008).

Cadmium is a non-essential metal and known to bioaccumulate in earthworms (Hopkin, 1989). The background concentrations of $\mathrm{Cd}$ in soil are usually around $1 \mathrm{mg}$ $\mathrm{kg}^{-1}$ dry weight (dw) or less (Keshavarz Jamshidian et al., 2017), but contaminated soils can have tens of $\mathrm{mg}$ of Cd (Spurgeon et al., 1994). Dissolved cadmium toxicity is well established in earthworms; with a 28-day lethal concentration (LC50) of $588 \mathrm{mg}$ $\mathrm{Cd} \mathrm{kg}^{-1} \mathrm{dw}$ in artificial soil (Van Gestel et al., 1991), and 56-day EC 50 for impairment of reproduction of $46.3 \mathrm{mg} \mathrm{Cd} \mathrm{kg}^{-1} \mathrm{dw}$ in artificial soil (Spurgeon et al., 1994). In contrast to $\mathrm{Cd}$, the ecotoxicity of tellurium is poorly understood. It has no known biological functions in eukaryotic cells (Ba et al., 2010) and not much is known about its toxicity to soil organisms. So far, the only known biological function of tellurium has been found in fungi, that can use tellurite instead of sulphur for production of amino acids when sulphur is limited or absent (Ramadan et al., 1989). Due to its biogeochemistry, Te is a difficult metalloid to measure in complex environmental matrices; nonetheless a few measurements of Te in soil and sediments are emerging, suggesting that it is naturally present at low $\mu \mathrm{g} \mathrm{kg}^{-1}$ concentrations (Belzile and Chen, 2015).

Studies on the environmental toxicology of QDs have shown biological effects that relate to the reactive chemical properties of CdTe QD; such as their potential to generate reactive oxygen species, but also toxicity related to $\mathrm{Cd}$ dissolution from the materials in various organisms (Rocha et al., 2017). Earthworms, like some other soil invertebrates, have the ability to sequester metals such as $\mathrm{Cd}$, and to form metal storage granules in the tissue (Brown, 1982). Earthworms also have the ability to 
biosynthesise CdTe QDs from dissolved metals (Stürzenbaum et al., 2013). There are some studies on neurotoxicity (Wu et al., 2015) and oxidative stress (Srivastava et al., 2016) in the nematode worm, Caenorhabditis elegans, with CdTe QDs; and at least one study on marine polychaete worms with CdS (Buffet et al., 2014). However, there is sparse information on the toxicity of additions of CdTe QDs to the soil for earthworms.

This experiment aimed to provide a 'baseline dataset' for the hazard of CdTe QDs in freshly prepared soil. The approach used the Organisation for Economic Cooperation and Development (OECD) technical guidance (TG) 222 method (OECD, 2004), but with modification and additional endpoints to give a detailed mechanistic understanding of the data. Recently, we also reported a coating related effect on the toxicity of CuO ENMs to earthworms (Tatsi et al., 2018). However, coating-mediated effects on the toxicity of CdTe QDs are unknown in earthworms, and exactly the same coatings were used here for the CdTe QDs ENMs. The study design therefore included a control soil, commercially available micron-sized (bulk) CdTe powder, and CdTe QDs made with organic surface coatings with terminal residues of carboxylate $(\mathrm{COOH})$, ammonium $\left(\mathrm{NH}_{4}{ }^{+}\right)$, or polyethylene glycol (PEG); to represent negative, positive and neutral surface charges respectively. The potentially toxic metal component(s) of the composite QDs were explored by determining the extractable metal fractions from soil compared to the observed accumulation of $\mathrm{Cd}$ and $\mathrm{Te}$ in the earthworm tissues. Also to enable some comparison with our previous experiments on CuO ENMs (Tatsi et al., 2018), the survival and growth of the earthworms in freshly dosed soils were determined. Biochemical measurements were also made in the fresh soil experiment to assess known mechanisms of metal toxicity including; effects on ionic regulation (tissue metal concentrations, $\mathrm{Na}^{+} / \mathrm{K}^{+}$-ATPase activity) and oxidative stress (total glutathione). Having established the response in fresh soil, a second experiment including similar endpoints was carried out with newly exposed earthworms after a six-month period of ageing the soils in order to understand the persistence of any hazard from CdTe QD materials in the soil.

\section{Methodology}

Two experiments were carried out using a low (50), medium (500) and high (2000 mg as CdTe $\mathrm{kg}^{-1} \mathrm{dw}$ ) nominal concentration of CdTe QDs in a quadruplicate test design. Unexposed controls and an equivalent CdTe micron-sized powder was 
used as a bulk material control. The first experiment was conducted with these substances freshly spiked into the soil, and the second experiment used the same soils after six months of ageing. Hereafter referred to as 'fresh' and 'aged' soil experiments, respectively.

\subsection{Engineered quantum dots and characterisation}

The ENMs used in the experiments were provided by PlasmaChem as part of a European Commission Framework 7 project (www.nanosolutionsfp7.com). The details of the coatings and their synthesis are commercially sensitive information. However, the different coatings were polyethylene glycol (PEG), carboxylate (COOH) and ammonium $\left(\mathrm{NH}_{4}^{+}\right)$to represent neutral, negative and positive coatings respectively. For clarity, we use the term ' $-\mathrm{NH}_{4}{ }^{+}$' to mean an $-\mathrm{NH}_{3}$ terminal ligand that has been ionised with $\mathrm{H}^{+}$ions to achieve positive charge. An appropriate micron-sized CdTe powder (size < $250 \mu \mathrm{m}$, Sigma-Aldrich, UK, CAS No. 1306-25-8) was used as a bulk material control (refer to hereafter as 'CdTe-bulk'). The materials were extensively characterised as part of the NANOSOLUTIONS project [e.g., (Vassallo et al., 2018)] and the characterisation of the batches of the materials used here is summarised in Table 1. This includes the nominal primary particle size and chemical composition of each nanoscale QD based on the manufacturer's information, as well as measurements of primary particle diameter, hydrodynamic diameter and dissolution of $\mathrm{Cd}$ and Te made in Plymouth (Table 1; Fig. S1). The QD powders supplied were dark red $\left(\mathrm{NH}_{4}{ }^{+}\right.$-coated) or bright red (PEG-, $\mathrm{COOH}$-coated) in colour and no impurities were identified by the supplier. The CdTe bulk powder was black in colour and no impurities were noted by Sigma-Aldrich. All other chemicals used were analytical grade and purchased from Sigma-Aldrich unless stated otherwise. The thermogravimetric analysis (TGA) of the materials (Table 1) tentatively indicated that the combustible organic components of the materials contributed roughly 8, 23 and $50 \%$ of the mass of the $\mathrm{CdTe}-\mathrm{NH}_{4}{ }^{+},-\mathrm{COOH}$ and $-\mathrm{PEG}$ coated QDs, respectively. However, this would include any 'unknown' organic impurities and potentially residual water molecules in between the polymers of the coatings. At the time of the study (and currently) it was not technically feasible to reliably quantify the molecular weight of the coatings in situ on the particles, or the precise stoichiometry or coverage of each coating in the overall material in order to spike the soils solely based on $\mathrm{Cd}$ or $\mathrm{Te}$ concentrations in the core. Therefore, pragmatically, the same approach was taken as 
we had done previously with $\mathrm{CuO}$ materials of the same coatings (Tatsi et al., 2018), where the mass concentration of the whole material as CdTe QDs was used for dosing and reported as $\mathrm{mg} \mathrm{CdTe} \mathrm{kg}^{-1} \mathrm{dw}$ for each soil treatment, and with measurements of the metal concentrations in the soils and organisms to confirm the exposure.

\subsection{Stock animals and test soil}

Adult Eisenia fetida originating from a commercial supplier (Blades Biological, Kent, UK) were used from an internal age synchronised laboratory breeding culture held at University of Plymouth for both experiments. The test species were kept in an artificial medium that comprised of bark chippings (1/3), Irish Moss Peat (1/3) and loamy sand topsoil (1/3) with surplus horse manure (from un-medicated horses) as feed at a temperature of $20 \pm 1^{\circ} \mathrm{C}$. Adult earthworms between two to four months old, and with visible clitellum, were hand-selected for the experiments. The earthworms were acclimatised to the test soil (Lufa 2.2) with feed one week prior to the experiment. A standard sandy loam Lufa 2.2 (LUFA Speyer, Germany) soil was used with the following composition (supplier's information, mean $\pm \mathrm{SD}$, dry soil, $n=$ not specified): $\mathrm{pH}$ of $5.5 \pm 0.2$ (measured in $0.01 \mathrm{M} \mathrm{CaCl}_{2}$ solution); organic carbon, $1.8 \pm 0.2 \%$; nitrogen content at $0.17 \pm 0.02 \%$; cation exchange capacity, $10.1 \pm 0.2$ meq $100 \mathrm{~g}^{-1}$. The water-holding capacity of the soil was measured in-house and was (mean \pm SD,

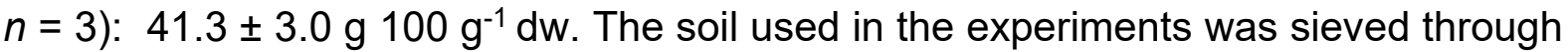
a $2 \mathrm{~mm}$ mesh and was air dried at $25^{\circ} \mathrm{C}$ for 2 days. Soil $\mathrm{pH}$ was measured (see Supplementary Information, Table S1) prior to the start and at the end of the experiment in a 1:1 soil: deionised water slurry, using a glass combination electrode (Corning 420).

\subsection{Experimental designs and spiking of the test soil}

\subsubsection{Fresh soil experiment}

The experiment was conducted using the standard OECD test guideline (TG) 222 for the earthworm reproduction test (OECD, 2004), but with a reduced number of earthworms and additional sub-lethal endpoints. The study design included an unexposed control soil, bulk-CdTe and the three variations of coated CdTe QDs: PEG, $\mathrm{COOH}, \mathrm{NH}_{4}{ }^{+}$at nominal concentrations of 50,500 and $2000 \mathrm{mg} \mathrm{CdTe} \mathrm{kg}{ }^{-1} \mathrm{dw}$. The 50 and $500 \mathrm{mg} \mathrm{CdTe} \mathrm{kg}^{-1} \mathrm{dw}$ concentrations were selected on the basis of the known sub-lethal effects and 28-day lethal concentration for $\mathrm{Cd}$ toxicity to earthworms 
respectively (Spurgeon et al., 1994; Van Gestel et al., 1991); and would also encompass the range of concentrations of $\mathrm{Cd}$ at contaminates sites such as metal smelters [e.g., 0.2-102 mg Cd kg-1 of soil, (Chlopecka et al., 1996)]. The TG 222 protocol allows a high dose of $1000 \mathrm{mg} \mathrm{kg}^{-1} \mathrm{dw}$ of the test substance in the soil as part of a 'limit test.' Given that the CdTe QDs are a composite of $\mathrm{Cd}$, Te, plus any coating; an upper concentration of $2000 \mathrm{mg} \mathrm{kg}^{-1} \mathrm{dw}$ was used for the QDs so that the individual metals in the composite might approximate to the limit test values in TG 222. It was also intended as a high concentration to reveal any mechanistic aspects of the toxic effects that might be observed. The QDs were mixed into the soil as powders, because dry mixing has been found a suitable dosing method (Handy et al., 2012). The amount of QD powder required to dose each of 4 replicates was weighed into $50 \mathrm{~g} \mathrm{dw}$ of soil and carefully mixed by hand for 10 minutes. Then, this aliquot of soil was added to the remaining amount of soil $(950 \mathrm{~g})$ and further mixed by hand, followed by wetting of the soil to $50-60 \%$ of the WHC with ultrapure Milli-Q water $(18.2 \Omega)$. The soil was left to equilibrate with the moisture for one day to minimise the risk of the QDs changing before the worms were added.

Adult $E$. fetida ( $n=5$ earthworms $/ 250 \mathrm{~g} \mathrm{dw}$ soil) with a mean weight of $1.86 \pm$ $0.02 \mathrm{~g}$ for 5 earthworms (mean \pm SEM, $n=52$, individual earthworm weight $\sim 0.36 \mathrm{~g}$ ) were exposed in 4 replicates boxes of soil at $20 \pm 1^{\circ} \mathrm{C}$ at $12: 12$ light:dark cycle. The earthworms were fed dried horse manure ( $1 \mathrm{~g} / \mathrm{earthworm}$ ) wetted to $70 \%$ of its water holding capacity (WHC) with Milli-Q water. Life history traits such as survival and weight of the earthworms were recorded at the beginning of the experiment and on days 14 and 28. Behavioural changes such as avoidance of burrowing into the soil, were recorded following visual assessment in all treatments at the beginning of the fresh soil experiment. Further endpoints such as total concentration of $\mathrm{Cd}$, Te and other elements in earthworm tissue and total glutathione and $\mathrm{Na}^{+} / \mathrm{K}^{+}-\mathrm{ATPase}$ activity, were measured on day 28 in randomly selected earthworms ( $n=8$ earthworms for each analysis per treatment; methods described below). After 28 days, when all the adults were removed from soils, additional feed was added $(5 \mathrm{~g} \mathrm{dw}$, wetted to $70 \%$ WHC with Milli-Q water) and soils were left for a further 28 days to allow juveniles to hatch from cocoons. The juveniles were then counted following the OECD TG 222 (OECD, 2004). Briefly, each test vessel was placed in a water bath $\left(60^{\circ} \mathrm{C}\right)$ and the juveniles that emerged to the surface were collected and counted. After counting, soils were manually checked to ensure no juveniles or cocoons remained in the soil. The 
juveniles collected from each treatment were washed in deionised water, blotted dry, and weighed to determine the treatment effect on juvenile growth.

\subsubsection{Aged soil experiment}

The soil used in the aged soil experiment was the same as that used in the initial fresh soil experiment. At the end of the fresh soil experiment the test containers were left for a total of 27 weeks (6 months) in the same experimental conditions, but without any disturbance or watering. During the ageing period the containers were not open, but airflow occurred via the pierced lids. Incidental plant growth had occurred during the ageing period, from seeds likely present in the natural soils or the manure used as feed. It was not an objective of the study to investigate plant growth in the aged soils, but the opportunity was taken. The plant coverage in each exposure container was quantified one day before starting the aged soil experiment. All the containers were photographed, and their percent cover with plants was determined by directly assessing the boxes (an acetate paper with grids was placed on each box to aid the estimation of percent cover). Once the above ground material was quantified (see supplementary material, Figs. S2 and S3), it was removed by cutting. The roots of the plants were left in the soil to increase the environmental realism of the aged soil study. Soil moisture content was then adjusted to 50 - $60 \%$ and soil pH was measured in a 1:1 soil:water slurry using a glass combination electrode (Corning instruments).

The same study design and methods were used in the aged soil experiment as described in the fresh soil experiment. Five earthworms with a mean weight of $1.89 \pm$ $0.03 \mathrm{~g}$ (mean \pm SEM, $n=52$, individual weight $\sim 0.38$

g) were used in the experiment. On days 0,14 and 28, endpoints such as survival, biomass and appearance were recorded. Reproduction was assessed after 56 days of exposure (described above). In addition, the total concentration of $\mathrm{Cd}$, $\mathrm{Te}$ and other electrolytes and trace metals in earthworm tissues were measured on day 28. Due to a technical fault with a freezer, earthworm samples collected for biochemical analyses (total glutathione and $\mathrm{Na}^{+} / \mathrm{K}^{+}-$ ATPase) were defrosted twice. These defrosted samples were analysed, but the results were considered unreliable and therefore not used (data not shown). In addition, juvenile weight was not assessed in the aged soil study due to the difficulty of obtaining the alive and intact juveniles from the soil. This was due to the presence of plant roots in the soil that severely hampered the collection of juveniles. The roots were inevitably very tangled in the soil, making it difficult to manually find and remove 
261 the juvenile worms that were extremely delicate. Several individuals stuck in the soil for too long and, unfortunately, they did not survive the handling stress of the collection procedure.

\subsection{Total and extractable metal analysis in samples}

Total metal analysis in the soils and the earthworms was conducted to confirm the exposure and the bioavailable fraction from the QDs, respectively, exactly as previously described (Tatsi et al., 2018). Total aqua regia extractable $\mathrm{Cd}$ and Te concentrations were measured in triplicate at the beginning of both the fresh and aged soil experiments ( $n=12$ per treatment). Additionally, to provide insight to the mobile fractions of $\mathrm{Cd}$ and $\mathrm{Te}$, water (deionised water) and $0.1 \mathrm{M} \mathrm{HCl}$ extractable fractions were determined in duplicate in the nominal $2000 \mathrm{mg} \mathrm{CdTe} \mathrm{kg}^{-1} \mathrm{dw}$ exposures only in the fresh soil experiment ( $n=8$ per treatment), aged soils were not analysed. Earthworms collected at the end of the fresh and aged soil experiments $(n=8$ per treatment) were allowed to depurate for $24 \mathrm{~h}$ on moist filter paper (the latter was changed following $12 \mathrm{~h}$ to avoid coprophagy) according to (Arnold and Hodson, 2007). Then the worms were washed, freeze-dried (for $48 \mathrm{~h}$ ), weighed and digested in $1 \mathrm{ml}$ concentrated $\mathrm{HNO}_{3}$. All acid digested samples were allowed to cool, diluted with $7 \mathrm{ml}$ ultrapure deionised water (18.2 $\Omega$ ) and stored in the dark. The total concentration of $\mathrm{Cd}$ and Te was measured in the soil and earthworm samples. In earthworms, also other essential elements ( $\mathrm{Ca}, \mathrm{Fe}, \mathrm{K}, \mathrm{Mg}, \mathrm{Mn}, \mathrm{Na}, \mathrm{Zn}, \mathrm{Cu}$ ) were measured to assess changes in the trace element and electrolyte composition of the earthworms by inductively coupled plasma optical emission spectrophotometry (ICP-OES, iCAP 700, Thermo Fisher) or inductively coupled plasma mass spectrometry (ICP-MS, Thermo Scientific $X$ Series 2) as appropriate. Prior to analysis, the samples were sonicated for 15 minutes (at $0.05 \mathrm{kva}, 30 \mathrm{kHz}$, Ultrawave Ltd), vortexed for $10 \mathrm{~s}$, then hand shaken immediately prior to analysis to ensure good mixing. All samples were analysed against matrix-matched standards where possible. The certified reference materials for total $\mathrm{Cd}$ metal reported close to the expected values and were $100 \pm 4 \%(n=3$, EnviroMAT contaminated soil, SS-1) and $102 \pm 7 \%(n=3$, TORT-2, contaminated lobster hepatopancreas). Spike recovery tests of earthworm and soil digests using CdTe- $\mathrm{NH}_{4}{ }^{+}$QDs were 78 and $73 \%$, respectively (values were calculated based on the sum of [Cd] and [Te] and normalised to expected coating mass which was $8.8 \pm 0.5 \%$ for $\mathrm{NH}_{4}{ }^{+}$). Using $\mathrm{CdCl}_{2}$ and Te standard for ICP-MS and -OES (TraceCERT by Sigma), 
the recoveries for earthworm and soil digests were $>90 \%$. The calculated limit of detection (LOD) for Cd (analysed by ICP-OES) was $1 \mathrm{mg} \mathrm{kg}^{-1} \mathrm{dw}$ and $0.001 \mathrm{mg} \mathrm{kg}^{-1}$ for $\mathrm{Cd}$ in soil and earthworm tissue, respectively. While the calculated LOD for Te (analysed by ICP-MS) was to around $0.01 \mathrm{mg} \mathrm{kg}^{-1} \mathrm{dw}$ and $0.1 \mathrm{mg} \mathrm{kg}^{-1} \mathrm{dw}$ in soil and earthworm tissue, respectively.

\subsection{Biochemical analyses}

The biochemical methods had been used previously for ENMs and earthworms in our laboratory (Tatsi et al., 2018). Biochemistry was performed on whole earthworm tissues collected at the end of fresh soil experiments ( $n=8$ per treatment). Earthworms from each test container were snap frozen in liquid nitrogen and stored at $-80{ }^{\circ} \mathrm{C}$ until homogenised in ice cold isotonic buffer (1:5 ratio, weight: volume) exactly as described in Tatsi et al. (2018). The homogenates were further diluted prior to analysis due to high protein concentration (15 fold dilution of the original tissue, $n=8$ per treatment) and were then were assayed in triplicate for total protein, total glutathione (GSH) and $\mathrm{Na}^{+} / \mathrm{K}^{+}$-ATPase activity exactly as described in Tatsi et al. (2018) and using a VersaMax plate reader (Molecular Devices, UK). Briefly, GSH was quantified in $20 \mu \mathrm{l}$ of the diluted homogenate according to (Owens and Belcher, 1965). $\mathrm{Na}^{+} / \mathrm{K}^{+}$-ATPase activity was determined in $10 \mu \mathrm{l}$ of the diluted homogenate based on a modification of (McCormick, 1993). Total protein was determined in $25 \mu \mathrm{l}$ of the diluted homogenate using the Pierce BCA kit (\#RE232674, Thermo Scientific, UK). The concentrations of GSH and $\mathrm{Na}^{+} / \mathrm{K}^{+}$-ATPase activity were normalised to total protein in the sample and data are expressed as nmol GSH per mg protein and $\mu$ mol ADP per mg protein per hour, respectively.

\subsection{Statistical analyses and data presentation}

Statistical analyses were performed using $R$ studio software (version 2.1) and graphs were drawn using SigmaPlot (version 13.0 or 14.0). Data were checked for normality (Shapiro-Wilk) and homogeneity of variance (Bartlett's test). Non-parametric data were transformed $\left(\log _{10}\right)$ and reanalysed as appropriate. The student's $t$-test (twotailed, un-/paired) or Mann Whitney test were used for comparing two samples sets as appropriate. Due to a few individual significant differences in $\mathrm{pH}$ between treatments in the fresh or aged soil experiments, analysis of covariance (ANCOVA) was carried out for the interactive effects of $\mathrm{pH}$ on all endpoints. When no interactions were found, 
$329 \mathrm{pH}$ was omitted from the model to allow the performance of a post-hoc test. Treatment 330 effects were assessed by one-way ANOVA followed by the Tukey-Kramer (due to unequal sample size) post hoc test. Changes in biomass were analysed with repeated measures ANOVA followed by Tukey's honest significance difference (HSD) test to identify the differences. The non-parametric Kruskal-Wallis test was used followed by a distribution free multiple comparisons test, Dunn's test, where data transformation was unsuccessful. To evaluate the biological associations known for metal toxicity, the Spearman's rank, rs, correlations were carried out on all of the data, regardless of treatment, for a specified endpoint within each experiment. The reproduction results were normalised to the control values and the $50 \%$ effect concentration $\left(\mathrm{EC}_{50}\right)$ values and its $95 \%$ confidence intervals were estimated by logistic nonlinear regression analysis (sigmoid) on raw data using the log-transformed nominal concentrations in SigmaPlot v 14.0. To estimate the nominal effect value, the log-transformed value was reversed. The statistical significance level $(\alpha)$ for all tests was set at 0.05 .

\section{Results}

3.1 Soil $\mathrm{pH}$

In the beginning of the fresh soil experiment the soil $\mathrm{pH}$ ranged from 5.36 to 5.89, and soil pH differed between QD treatments and the control soils. However, by the end of the exposure (day 28) there were no differences in $\mathrm{pH}$ between the QDtreated soils and the control soils, with the $\mathrm{pH}$ values ranging from 5.39 to 5.78 (Table S1). In the aged soil experiment, the $\mathrm{pH}$ ranged from 5.38 to 5.65 , both at the beginning and the end of the experiment, and was not statistically different from the corresponding $\mathrm{pH}$ measurements in the fresh soil experiment $(P>0.05$, Student's $t$ test). Soil $\mathrm{pH}$ was included as a cofactor in all the endpoints analysed in both experiments, but no significant interactions were found $(P>0.05$, ANCOVA). Soil $\mathrm{pH}$ was therefore not a factor in any of the biological measurments.

\subsection{Total and extractable Cd and Te concentrations in soil}

To enable the interpretation of the results, the total aqua regia extractable concentration of $\mathrm{Cd}$ and Te was measured at the beginning of both the fresh and aged soil experiments. In the former experiment, the control soil contained a background Cd concentration of $0.61 \pm 0.05 \mathrm{mg} \mathrm{Cd} \mathrm{kg}^{-1} \mathrm{dw}$ (mean $\pm \mathrm{SEM}, n=8$ ), of this total $\mathrm{Cd}$, 
that less than $10 \%$ of the $\mathrm{Cd}$ in the soil was mobile. Te was not detected in the control soil, as the results were below the limit of detection, $<0.01 \mathrm{mg} \mathrm{Te} \mathrm{kg}^{-1} \mathrm{dw}$. Since the CdTe QDs were dosed into the soil on the basis of the mass of the whole material, including both metals present and any coating, it was expected that the measured total $\mathrm{Cd}$ and Te concentrations (i.e., measured concentration of each metal) would be a fraction of the total exposure concentration of the whole material. This was indeed the case (Fig. 1). Nonetheless, exposure to CdTe bulk and the differently coated CdTe QDs caused the expected increase in total soil Cd concentrations in the fresh soil experiment (Fig. 1). However, the measured total $\mathrm{Cd}$ in the soil did not differ significantly between the types of CdTe QD exposures within each nominal test concentration (Fig. 1, $P>0.05$, ANOVA). The measured total Te concentrations also increased with the nominal exposure concentration of the whole material in the fresh soil experiment. However, in contrast to $\mathrm{Cd}$, the total tellurium concentration varied significantly between materials in each nominal test concentration (Fig. 1A and B, $P<$ 0.05 , ANOVA); with the amount of Te in the exposures followed the order of: $\mathrm{COOH} \leq$ PEG $<\mathrm{NH}_{4}{ }^{+}<\mathrm{CdTe}$-bulk. This was not interpreted as a 'coating effect' per se, because it did not follow the order of mass loss of the materials in the TGA measurement of PEG $>\mathrm{COOH}>\mathrm{NH}_{4}{ }^{+}$(Table 1) and in any case, the effect was absent in the $\mathrm{Cd}$ measurements. Instead, this was likely attributed to the ratio of $\mathrm{Cd}$ to $\mathrm{Te}$ in the different materials as manufactured.

The water- and dilute acid-extractable $\mathrm{Cd}$ or Te was measured at the beginning of the fresh soil experiment at the highest nominal exposure concentration and plotted against the total metal concentrations in the earthworms (Fig. 2). The amount of waterand $0.1 \mathrm{M} \mathrm{HCl}$-extractable $\mathrm{Cd}$ and Te varied between treatments. In the CdTe-bulk exposures, less than $1 \%$ of the $\mathrm{Cd}$ and Te were extractable and the $\mathrm{Cd}$ or Te metal concentrations in the earthworms were also modest (Fig. 2); suggesting low availability of metal from the bulk material in the soil. For the CdTe QD treatments, regardless of the extraction method or type of coating, only a small proportion of the Te was extractable and with similarly low total Te concentrations in the earthworms. However, the situation was different for the extractable Cd from the QDs (Fig. 2), with a considerable fraction of acid-extractable $\mathrm{Cd}$ in the soil. Overall, with the $\mathrm{QD}$ treatments, the water available fraction of $\mathrm{Cd}$ and Te was the highest from CdTe- $\mathrm{NH}_{4}{ }^{+}$ QD exposures, although this did not necessarily lead to a concomitant elevation of total $\mathrm{Cd}$ or Te in the earthworms according to the type of coating (Fig. 2). The total 
concentration of $\mathrm{Cd}$ and $\mathrm{Te}$ in the soil were measured again prior to beginning of the aged soil experiment. In general, the concentration of $\mathrm{Cd}$ and $\mathrm{Te}$ in the aged soil followed a very similar pattern to the fresh soil experiment, but with a trend (not statistically significant) of slightly lower values than in the fresh soil experiment. The extractable fractions were not assessed in the aged soils.

\subsection{Total $\mathrm{Cd}$ and $\mathrm{Te}$ in earthworm tissue}

The total $\mathrm{Cd}$ or Te concentrations in the earthworms are shown in Fig. 3. The control earthworms in the both the fresh and aged experiments had some background $\mathrm{Cd}$ in the tissues ( $4.23 \pm 0.34 \mathrm{mg} \mathrm{Cd} \mathrm{kg}^{-1} \mathrm{dw}$, mean $\left.\pm \mathrm{SEM}, n=8\right)$, while no Te was detected. In the fresh soil experiment, an exposure concentration-dependent increase in the total body burden of Cd was seen in all the CdTe-bulk and all the CdTe QD exposures (Fig. 3). The accumulation of Cd was significantly lower in the CdTe-bulk when compared to the QD exposures in fresh soil at each exposure concentration. However, within the CdTe QDs, there was no significant differences between the total concentrations of $\mathrm{Cd}$ in the earthworm tissues by the type of coating of the CdTe QDs at each nominal test concentration (Fig. 3A, $P>0.05$, ANOVA). The total concentration of $\mathrm{Te}$ in the earthworms during the fresh soil experiment was also measured (Fig. 3B). Here, the tissue Te concentration increased in a concentrationdependent manner in the CdTe-bulk exposures, but not in the CdTe QD exposures where the Te remained uniformly low. Within the QDs there was also no clear effect on Te accumulation by the type of surface coating on the ENM in the fresh soil experiment (Fig. 3B). Together these observations suggest some Te accumulation for the bulk material, but very limited Te accumulation for CdTe QDs in fresh soil. The accumulation of $\mathrm{Cd}$ and Te were strongly correlated within each treatment group $\left(\mathrm{r}_{\mathrm{s}}=\right.$ 0.9, 0.8, 0.8 and 0.9 for CdTe-bulk, $-\mathrm{PEG},-\mathrm{COOH}$ and $-\mathrm{NH}_{4}{ }^{+}$exposures, $P<0.05$, Spearman) and this is consistent with the notion of being exposed to a composite material containing both metals. The total $\mathrm{Cd}$ or $\mathrm{Te}$ in the soil was also significantly correlated to the total $\mathrm{Cd}$ or $\mathrm{Te}$ in earthworms when analysing all the data together $\left(\mathrm{r}_{\mathrm{s}}\right.$ $=0.8$ and 0.7 for $\mathrm{Cd}$ and $\mathrm{Te}, P<0.05$, Spearman); and within the animals in each treatment. However, this contrasts with the absence of any clear relationship between the water- or acid-extractable fractions and accumulation of $\mathrm{Cd}$ or $\mathrm{Te}$ by the earthworms noted in Fig. 2. 
In the aged soil experiment, the accumulation of $\mathrm{Cd}$ and Te by earthworms was, overall, higher than in the fresh soil experiment. In the CdTe-bulk exposures the Cd concentrations in the earthworms were significantly higher than those in the fresh soil study (Fig. 3). In the nominal $50 \mathrm{mg} \mathrm{CdTe} \mathrm{kg}^{-1} \mathrm{dw}$ test concentration there were no significant differences in the concentration of $\mathrm{Cd}$ in the earthworms by the type of coating on the CdTe QDs in the aged soil (Fig 3C). In the nominal 500 or $2000 \mathrm{mg}$ CdTe kg-1 $\mathrm{dw}$ test concentrations in aged soil, there were no statistically significant differences between the tissue concentrations of $\mathrm{Cd}$ between doses, but there was a trend of higher tissue $\mathrm{Cd}$ concentration in earthworms exposed to the differently coated CdTe QDs when compared to the CdTe-bulk, although the trend was not statistically significant. In the aged soil experiment, the concentration of Te in the earthworms followed a similar pattern of accumulation to the fresh soil experiment, where the highest amount of Te was found in earthworms exposed to CdTe-bulk material in all test concentrations. In the nominal $50 \mathrm{mg} \mathrm{CdTe} \mathrm{kg}^{-1} \mathrm{dw}$ test concentration, there were no statistically significant differences in Te accumulation by the type of coating on the CdTe QDs. However, some differences in the total Te

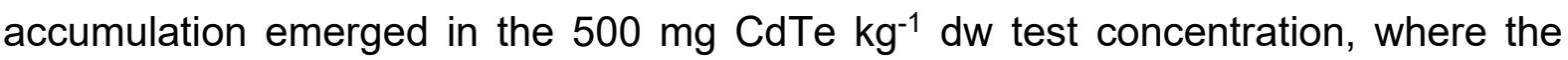
concentration was highest in the CdTe- $\mathrm{NH}_{4}{ }^{+}$QD exposure, compared to the other materials, and the Te accumulation was similar in the CdTe-PEG and -COOH QD

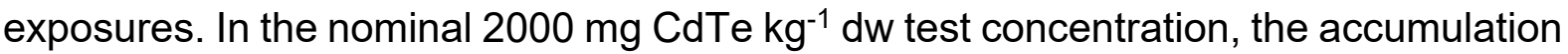
of Te was not statistically significantly different between the different CdTe QD exposures, although there was a non-significant trend of higher Te in the CdTe- $\mathrm{NH}_{4}{ }^{+}$ groups.

453

\subsection{Survival, biomass and appearance of earthworms}

455

The survival and biomass (growth) of the earthworms are reported in Table 2 for both the fresh and aged soil experiments. First, consider the fresh soil experiment.

457 The control animals were healthy and increased in biomass (19.9 $\pm 5.1 \%$, Table 2). In the fresh soil experiment, there were no statistically significant changes in the survival in any of the treatments throughout the experiment, except some minor mortalities < $10 \%$. The biomass of earthworms in the CdTe-bulk exposures also increased by as much as $22 \%$ by day 28 (Table 2); overall indicating no effects on growth or survival of earthworms exposed to the bulk material compared to the unexposed controls in the fresh soil experiment. An increase in biomass was also 


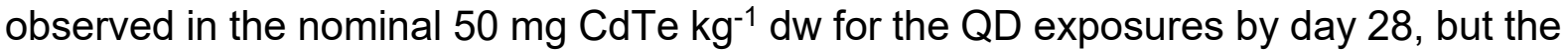
$2000 \mathrm{mg} \mathrm{CdTe} \mathrm{kg}^{-1} \mathrm{dw}$ exposure concentration of the QDs caused a uniform decrease in biomass of around $50 \%$ by day 28 , regardless of the type of coating on the ENMs (Table 2). There were no obvious behavioural or changes in appearance of the earthworms exposed to the CdTe-bulk or the nominal 50 and $500 \mathrm{mg} \mathrm{CdTe} \mathrm{kg}^{-1} \mathrm{dw}$ of the CdTe QDs in the fresh soil experiment. However, earthworms from all the CdTe

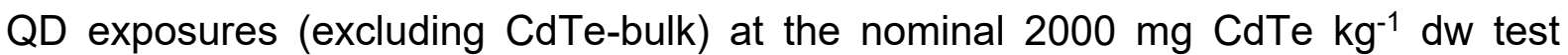
concentration were sluggish and were not actively feeding (evidence of left-over manure), although they were still moving in the soil. Furthermore, morphological changes were evident in earthworms from the $2000 \mathrm{mg} \mathrm{CdTe} \mathrm{kg}^{-1} \mathrm{dw}$ CdTe QD ENM exposures. The earthworms were visibly smaller and showed evidence of shedding of the posterior segments (the last segments were clearly lighter coloured with signs of regeneration). A strong negative correlation was found between tissue $\mathrm{Cd}$ or $\mathrm{Te}$ and biomass for the fresh soil experiment when analysing all the data from all treatments together ( $r_{s}=0.6$ and 0.5 for $C d$ and Te respectively, $P<0.05$, Spearman).

In the aged soil study, the control earthworms were healthy in appearance and with good survival, however, a trend of biomass loss $(8.1 \pm 5.6 \%$, Table 2$)$ was noted, although the change was not statistically significant. The earthworms survived in all the CdTe-bulk exposures with only minor mortalities $<10 \%$ at the nominal $2000 \mathrm{mg}$ CdTe $\mathrm{kg}^{-1} \mathrm{dw}$ exposures in the aged soil experiment. In the CdTe-bulk exposures, earthworms lost biomass only at the nominal $2000 \mathrm{mg} \mathrm{CdTe} \mathrm{kg}^{-1} \mathrm{dw}$ test concentration (Table 2). At the nominal $2000 \mathrm{mg} \mathrm{CdTe} \mathrm{kg}^{-1} \mathrm{dw}$ test concentration for the CdTe QDs, the $\mathrm{CdTe}-\mathrm{COOH}$ QDs were the most toxic to earthworms in the aged soil experiment; where survival was reduced to $55 \pm 5,60 \pm 25$, and $75 \pm 10 \%$ for the $-\mathrm{COOH},-\mathrm{NH}_{4}{ }^{+}$ and-PEG-coated QDs respectively by day 28 (Table 2). In addition, earthworms from these treatments showed statistically significant weight loss compared to controls. There were no obvious behavioural or appearance changes in the CdTe-bulk exposures or the nominal $50 \mathrm{mg} \mathrm{CdTe} \mathrm{kg}^{-1} \mathrm{dw} \mathrm{CdTe}$ QD exposures in the aged soil experiment. Some earthworms appeared lethargic and non-responsive in the 500 and $2000 \mathrm{mg} \mathrm{CdTe} \mathrm{kg}^{-1} \mathrm{dw}_{\mathrm{C}} \mathrm{CdTe}$ QD ENM exposures, and similar to the fresh soil study, there was evidence of shedding of the posterior segments and lack of feeding (presence of surplus feed). 


\subsection{Reproduction}

The reproductive success of the animals is reported in Table 3, and with doseresponse curves for juvenile production shown in Fig. S4. The test results on reproduction in the controls of both fresh and aged experiments met the validity criteria of the OECD TG 222. In both the experiment with fresh and aged soil, the control earthworms produced a healthy number of juveniles per earthworm (Table 3), and with a coefficient of variation ( $\mathrm{CV} \%$ ) of less than $<30 \%$ in keeping with the OECD test. Reproduction was not significantly reduced in any of the CdTe-bulk test concentrations, or in the nominal $50 \mathrm{mg} \mathrm{CdTe} \mathrm{kg}^{-1} \mathrm{dw}$ CdTe QD exposures in the fresh soil experiment. However, it was significantly reduced in the CdTe QD treatments at

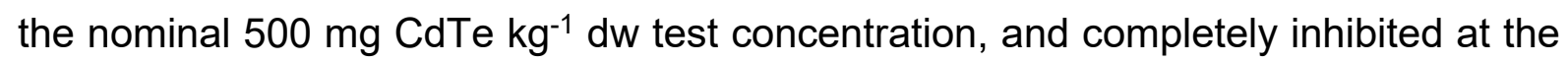
$2000 \mathrm{mg} \mathrm{CdTe} \mathrm{kg}^{-1} \mathrm{dw}$ test concentration for the CdTe QD exposures, compared to controls in the fresh soil experiment. The $50 \%$ effect concentrations (EC50) for reproductive success (i.e., juvenile production) for the different materials are presented in Table 3. The estimated $\mathrm{EC}_{50}$ values were calculated using the nominal CdTe QD concentrations (response curves presented in Fig. S4). For the fresh soil experiment, the $\mathrm{EC}_{50}$ values decreased in the following order: $\mathrm{CdTe}-\mathrm{COOH}<\mathrm{CdTe}-$ $\mathrm{NH}_{4}{ }^{+}<\mathrm{CdTe}-\mathrm{PEG}$. For the CdTe bulk material in fresh soil there was no inhibition of juvenile production and so an EC50 value could not be estimated. The fresh wet weight of the juveniles was also measured after they were rinsed in deionised water and padded dry (Table 3). There were some statistically significant differences between treatments in the biomass of the juveniles in the fresh soil experiment, but the differences followed the same order as the total number of juveniles produced. That is, where only a few juveniles were produced, those juveniles also tended to be small (i.e., poor quality offspring).

In the aged soil experiment (Table 3), the controls produced more juveniles than in the fresh soil experiment. Unlike the situation in fresh soil, the number of juveniles produced in the CdTe-bulk exposures declined, and with a complete

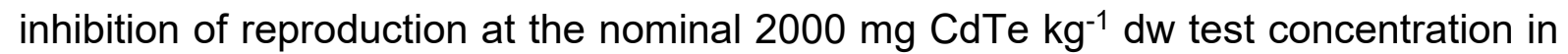
aged soil. The effects of the CdTe QD exposures on juvenile production were more pronounced in the aged soil experiment, with lower $\mathrm{EC}_{50}$ values for the CdTe-PEG and $\mathrm{CdTe}-\mathrm{NH}_{4}{ }^{+}$treatments in the aged soil compared to those in fresh soil (Table 3). The number of juveniles produced was significantly reduced or completely abolished

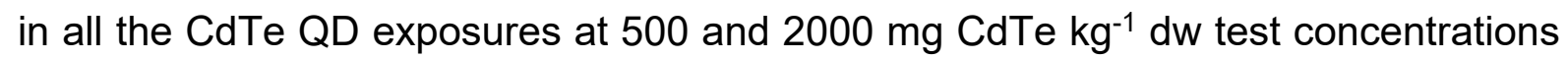


compared to the unexposed controls in aged soil. The $\mathrm{EC}_{50}$ values for reproductive success decreased in the following order in aged soil: $\mathrm{CdTe}-\mathrm{NH}_{4}{ }^{+}<\mathrm{CdTe}-\mathrm{COOH}<$ CdTe-PEG < CdTe-bulk. However, while the ranking of the $\mathrm{EC}_{50}$ values are correct, 534 all of the curve fits (Fig. S4), will have some uncertainty in the precise $\mathrm{EC}_{50}$ value due to the number of data points and their confidence intervals in the dose-response plot.

\subsection{Sodium pump activity and tissue elemental composition}

In the experiment with the fresh soil the control earthworms showed a normal $\mathrm{Na}^{+} / \mathrm{K}^{+}$-ATPase (sodium pump) activity $6-8 \mu \mathrm{mol}$ ADP $\mathrm{mg}^{-1}$ protein $\mathrm{h}^{-1}$ (Fig. 4A). In the fresh soil experiment, there was an overall trend of lower sodium pump activity in all the exposure concentrations of the CdTe bulk material, with significantly reduced activities in the nominal 500 and $2000 \mathrm{mg} \mathrm{CdTe} \mathrm{kg}^{-1} \mathrm{dw}$ test concentration (Fig. 4). There was also some inhibition of the $\mathrm{Na}^{+} / \mathrm{K}^{+}$-ATPase in the CdTe QD treatments in the fresh soil experiment, but with no clear dose and coating-dependent trend in the data (Fig. 4A). The substrates for the sodium pump include $\mathrm{Na}^{+}$and $\mathrm{K}^{+}$and the tissue electrolytes of the earthworms are shown in Table S2. There was no clear effect on the concentration of $\mathrm{Na}^{+}$in earthworm tissues, however, the concentration of $\mathrm{K}^{+}$was significantly lower in the nominal 500 and $2000 \mathrm{mg} \mathrm{CdTe} \mathrm{kg}{ }^{-1} \mathrm{dw} \mathrm{CdTe}-\mathrm{NH}_{4}{ }^{+}$ exposures compared to controls ( $P<0.05$, ANOVA; Table S2). In the aged soil study, unfortunately failure of a deep freeze prevented any reliable determination of enzyme activity in those samples (data not shown). However, there was no depletion or significant increase in the tissue concentration of $\mathrm{Na}^{+}$or $\mathrm{K}^{+}$between the test concentrations and the control for any treatment $(P>0.05$, ANOVA; Table S2).

A range of other electrolytes and essential trace elements in the tissues of the earthworms are shown in Table S2. Overall for the control earthworms, in both the fresh and aged soil studies, the electrolytes and trace elements remained in the expected range for a healthy earthworm population (Table S2). The earthworms in the fresh soil study exposed to the CdTe-bulk showed no significant treatment-dependent changes in electrolytes or trace metals (Table S2). In contrast, the CdTe QD exposures at 500 and $2000 \mathrm{mg} \mathrm{CdTe} \mathrm{kg}^{-1} \mathrm{dw}$ test concentrations showed statistically significant decreases in essential and trace metals in the earthworms in fresh soil (Table S2). The concentration of $\mathrm{Ca}, \mathrm{Mg}$ and Fe were significantly reduced in the

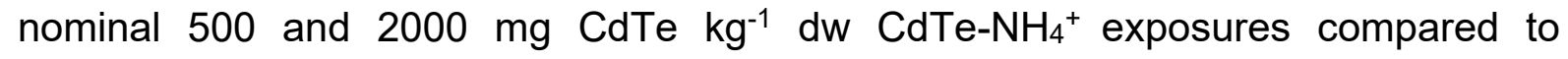
unexposed controls in the fresh soil experiment. There was also a significant negative 
correlation between the tissue concentration of $\mathrm{Cd}$ and the influenced metals $\left(r_{\mathrm{s}}=-\right.$ 0.3, -0.4 and -0.3 for $\mathrm{Ca}, \mathrm{Mg}$ and Fe respectively, $P<0.05$, Spearman). Earthworm tissue copper concentrations were significantly reduced, ranging from $5-6 \mathrm{mg} \mathrm{Cu} \mathrm{kg}$ 1 in nominal $500 \mathrm{mg} \mathrm{CdTe} \mathrm{kg}^{-1} \mathrm{dw} \mathrm{CdTe}-\mathrm{COOH}$ and $\mathrm{NH}_{4}{ }^{+}$and nominal $2000 \mathrm{mg} \mathrm{CdTe}$ $\mathrm{kg}^{-1} \mathrm{dw}$ CdTe-COOH exposures; compared to an expected concentration of $8-10 \mathrm{mg}$ $\mathrm{Cu} \mathrm{kg}{ }^{-1} \mathrm{dw}$ in controls in the fresh soil study. Manganese $(\mathrm{Mn})$ was significantly depleted in earthworms from the nominal $500 \mathrm{mg} \mathrm{CdTe} \mathrm{kg}^{-1} \mathrm{dw} \mathrm{CdTe}-\mathrm{NH}_{4}{ }^{+}$and nominal $2000 \mathrm{mg} \mathrm{CdTe} \mathrm{kg}^{-1} \mathrm{dw}$ CdTe-PEG, $\mathrm{COOH}$ and $\mathrm{NH}_{4}{ }^{+}$exposures, ranging from $14-15 \mathrm{mg} \mathrm{Mn} \mathrm{kg}^{-1} \mathrm{dw}$ compared to controls at $43 \mathrm{mg} \mathrm{Mn} \mathrm{kg}^{-1} \mathrm{dw}$ in the fresh soil study. A significant strong negative correlation was found between the tissue $\mathrm{Cd}$ and $\mathrm{Cu}$ or $\mathrm{Mn}$ ( $\mathrm{r}_{\mathrm{s}}=-0.6$ for both, $P<0.05$, Spearman).

In the experiment with the aged soil, there were no significant effects on the electrolytes in the earthworms, however trace metals, $\mathrm{Cu}$ and $\mathrm{Mn}$, were affected (Table S2). The concentration of Cu was significantly reduced compared to the control

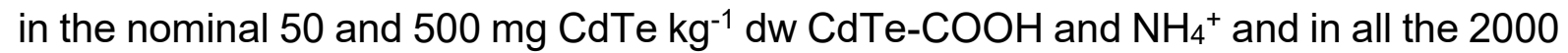
$\mathrm{mg} \mathrm{CdTe} \mathrm{kg}{ }^{-1} \mathrm{dw}$ exposures (ranging from $2-5 \mathrm{mg} \mathrm{Cu} \mathrm{kg}^{-1} \mathrm{dw}$ ). The concentrations of $\mathrm{Mn}$ were significantly reduced compared to the control only in the nominal $2000 \mathrm{mg}$ $\mathrm{CdTe} \mathrm{kg}{ }^{-1} \mathrm{dw} \mathrm{CdTe}-\mathrm{COOH}$ and $\mathrm{NH}_{4}{ }^{+}$exposures (ranging from $18-25 \mathrm{mg} \mathrm{Mn} \mathrm{kg}^{-1}$ $\mathrm{dw}$ ). There was also a significantly strong negative correlation between the tissue concentration of $\mathrm{Cd}$ and $\mathrm{Cu}$ or $\mathrm{Mn}\left(\mathrm{r}_{\mathrm{s}}=-0.5\right.$ for both, $P<0.05$, Spearman) in the aged soil experiment.

\subsection{Total glutathione as an oxidative stress marker}

Total glutathione (GSH) concentrations were measured as an oxidative stress markers in the earthworms (Fig. 4B). Earthworms from the fresh soil experiment sustained a normal total glutathione concentration $\left(\sim 16 \mathrm{nmol} \mathrm{mg}^{-1}\right.$ protein). In the CdTe-bulk exposures there was no significant effect on the total GSH concentration. Also, there was no significant effects in the differently-coated CdTe QD exposures when compared to the controls ( $P>0.05$, ANOVA). The results of the total GSH from the aged soil study were not considered reliable due to thawing of the frozen samples (data not shown).

\subsection{Quantification of plant material}


It was not the aim of this study to assess the effects of CdTe QDs on plants, but there was some incidental plant growth in the soil during the six months of ageing. Prior to the start of the aged soil exposures of the earthworms, the opportunity was taken to measure the plant cover on the exposure soils. The unexposed control soils had an overall cover of $>85 \%$ of plants and $\sim 80 \%$ of moss. Overall, effects on plant cover were evident only at the nominal 500 and $2000 \mathrm{mg} \mathrm{CdTe} \mathrm{kg}^{-1} \mathrm{dw}$ exposures (Fig. S2). There was a material size effect with the CdTe QDs being more toxic to plant growth than the CdTe QD bulk counterpart, and there was a coating-mediated effect for the QDs (Fig. S2). At the highest concentration of the CdTe bulk material, the vascular plant and moss cover was significantly reduced to around $20 \%$ of that in the controls (Fig. S2). Clear effects on plant cover were also evident in the nominal 500 mg CdTe $\mathrm{kg}^{-1} \mathrm{dw}$ CdTe QD exposures, where the PEG- and COOH-coated QDs showed the least amount of plants and moss, while the $\mathrm{CdTe}-\mathrm{NH}_{4}{ }^{+}$exposure was similar to the CdTe-bulk and the controls. However, at the highest QD ENM test concentrations there were no vascular plants or moss growth (Figs. S2 and S3), except in the CdTe-PEG treated soils, which had a very limited (around $10 \%$ ) moss cover. The highest CdTe QD treatments with no plant matter had a biofilm-like layer and some mould, and the soil had dried in places (Fig. S4).

616

\section{Discussion}

619

620

This is the first study to investigate the effects of CdTe QDs with different surface

621 coatings on earthworms compared against a micron-sized (bulk) CdTe material in fresh soil. The hazard to earthworms was also assessed after 6 months of ageing the soils. In the fresh soil experiment, none of the CdTe materials (bulk or ENMs) altered survival, but exposure to CdTe QDs caused a significant reduction in the number of juveniles produced and disturbances to essential metal concentrations in the earthworm tissues. There was also evidence of a coating-mediated effect, which altered the release of dissolved $\mathrm{Cd}$ and Te from the materials, rather than an effect due to the type of chemical substance in the coating itself. In the aged soil experiment, unlike the fresh soil study, the CdTe- $\mathrm{NH}_{4}{ }^{+}$QDs reduced the survival of the earthworms. 
631 production in the aged soil experiment compared to the fresh soil study, but the CdTe

632 QDs remained more toxic than CdTe-bulk QDs.

633

634

635

4.1 Extractable metal fractions in the soil in relation to $\mathrm{Cd}$ and $\mathrm{Te}$ accumulation by earthworms

The exposures were confirmed by measuring the total metal concentrations of $\mathrm{Cd}$ and Te in the soil (Fig. 1), and in the earthworms (Fig. 3). For the unexposed controls, the background concentration of Cd in Lufa 2.2 soils was low $(0.6 \pm 0.2 \mathrm{mg}$ $\mathrm{Cd} \mathrm{kg}^{-1} \mathrm{dw}$, Figure 1) and consistent with previous reports for the same soil [e.g., 0.38 mg Cd kg-1 dw, (Keshavarz Jamshidian et al., 2017)]. In the control soil, less than $10 \%$ of the total background $\mathrm{Cd}$ concentration was water and acid extractable, indicating that the background $\mathrm{Cd}$ in the control soil was not mobile. There was no Te detected in the control soils, as expected for a rare metalloid with very low background concentrations in unpolluted soil [e.g., values $<5 \mu \mathrm{g} \mathrm{kg}^{-1} \mathrm{dw}$, (Belzile and Chen, 2015)]. The background concentration of $\mathrm{Cd}$ in the earthworms was also in agreement with previous studies using the same soils $\left[4.23 \pm 0.34 \mathrm{mg} \mathrm{Cd} \mathrm{kg}^{-1} \mathrm{dw}\right.$ this study; 5.6 mg Cd kg-1 (González et al., 2013)], while tissue Te concentration remained below the detection limit.

The soils treated with CdTe QDs had elevated $\mathrm{Cd}$ and Te concentrations compared to the unexposed control soils, and as expected, the measured metal concentrations increased with the nominal exposure concentration. This occurred in both the fresh and aged soil experiments (Fig. 1). However, within each soil dose for each type of CdTe QD, there was also some slight variation in the measured concentration of total $\mathrm{Cd}$ or Te according to the type of coating on the starting material. This was likely due to the stoichiometry of the materials giving rise to slightly different ratios of $\mathrm{Cd}$ or Te to the coating, by mass. The effect was small within each soil dose, and only influenced the Te measurements in the soil for the CdTe-PEG and CdTe$\mathrm{COOH}$ materials (Fig. 1). This was very similar to our previous findings on CuO ENMs that had the same coatings; where the proportion of the overall mass due to the particle core relative to the coating inevitably varied with the type of coating (Tatsi et al., 2018). Nonetheless, in the present study, within each type of coating on the CdTe QDs, the ratios of the measured $\mathrm{Cd}$ and Te concentrations in the soil were consistent for that 663 material. 
In the fresh soil experiment, attempts were made to determine the bioaccessible fractions of $\mathrm{Cd}$ and $\mathrm{Te}$ in the soil. The water- and acid-extractable fractions of metals from the soils were plotted against the measured metal concentrations in the earthworms (Fig. 2). For the unexposed controls, the $\mathrm{Cd}$ or Te concentrations were very low or at the detection limit, as expected. The CdTe bulk material also revealed very low water- or acid-extractable metal concentrations (e.g., water-extractable of around $0.1 \mathrm{Cd} \mathrm{kg}^{-1} \mathrm{dw}$ or $0.035 \mathrm{mg} \mathrm{Te} \mathrm{kg}^{-1} \mathrm{dw}$ of soil, Figs. $2 \mathrm{C}$ and D), which represented $<1 \%$ of those metals in the bulk material exposures. The CdTe bulk materials also showed negligible metal dissolution (Fig. S1). Together, this suggests the metals in the CdTe bulk material are not bioaccessible as dissolved metals to the earthworms, and that the observed $\mathrm{Cd}$ and Te accumulation in the earthworms was attributed to uptake of the intact CdTe bulk material. The concentration of $\mathrm{Cd}$ compared to Te in the earthworm tissue (compare panels $\mathrm{A}$ and B in Fig. 3 for fresh soil) was consistent at around 1.7 which also indicates some accumulation of the intact CdTe bulk material.

The situation was somewhat different for the ENMs in soil compared to the bulk material (Fig. 2), with all the CdTe QDs showing a water- and acid-extractable fraction of $\mathrm{Cd}$ in the soil, but not much extractable Te. The dialysis experiment also showed more dissolution of $\mathrm{Cd}$ than Te from the ENMs (Fig. S1); which together implies the Cd was more bioaccessible than the Te in CdTe QDs. Furthermore, the Cd accumulation in the earthworms was at least an order of magnitude higher than $\mathrm{Te}$ (Figs. 2 and 3), despite no such differences in the exposure concentration of the metals in the soil from the ENMs (Fig. 1). This observation can only be explained by the differential uptake and/or retention of Cd compared to Te in the tissues, and therefore that the CdTe QDs do not remain intact. It has been suggested that CdTe QD likely degrade in the soil to release dissolved Cd (Navarro et al., 2008). In aqueous media for algae, the dissolution of Cd from CdTe-containing QDs and subsequent free metal ion uptake can explain most of the $\mathrm{Cd}$ accumulation by the organisms [Chlamydomonas reinhardtii, (Domingos et al., 2011)]. Differential accumulation of Cd and Se have been noted in earthworms exposed to CdSe QDs [9-20 nm, (Stewart et al., 2013)]. Fluorescence imaging has shown what appears to be intact CdTe QDs (assumed from the fluorescence signal itself) in the gut lumen of the nematode, $C$. elegans, (Qu et al., 2011) and the gastrointestinal tract of larvae of the leaf roller moth 
inside the cells of the internal organs, it does suggest that CdTe QDs can be presented to the gut of terrestrial organisms. Regardless, the contrasting behaviour of the CdTe bulk material to remain intact with negligible dissolution, compared to the nano forms which show some dissolved $\mathrm{Cd}$, may simply arise from size-dependent effect on the surface to volume ratio of the materials, although further experiments are needed to verify this.

In contrast to knowledge on the biology of $\mathrm{Cd}$, there are almost no studies on Te accumulation in earthworms. The Te was not extractable from CdTe QDs (Fig. 2) and so not very bioaccessible. Te was not accumulated as strongly as $\mathrm{Cd}$ (compare Fig. $3 \mathrm{~A}$ with $3 \mathrm{~B}$ in the fresh soil experiment) and there was also no clear dosedependent increase in the tissues. For the low concentrations of Te found in the earthworms, this may suggest that either earthworms are effectively excreting $\mathrm{Te}$, or the unidirectional uptake mechanism (currently unknown for Te) is much slower than that for $\mathrm{Cd}$. However, once inside the tissue, it has been suggested that dissolved $\mathrm{Cd}$ and Te may together form biogenic CdTe QDs (Stürzenbaum et al., 2013). The mineralisation of biogenic particles in earthworms from dissolved metals is well known (Brown, 1982), so the presence of particles in the tissue may not infer uptake of the intact original material.

\subsection{Nanomaterial coating-mediated effects on metal accumulation}

A central concern for the environmental risk assessment of ENMs is whether or not any particle coating-related effects would make the bioaccumulation potential of materials so different, that each form and type of coating would be required to be treated as a new substance with respect to the regulation of chemicals. Similarly, there are concerns that the transformation of particles in the environment would lead to different hazards compared to the original 'pristine' ENM (Gardea-Torresdey et al., 2014; Lowry et al., 2012). First consider the issue of coating effects on bioaccumulation. The water- and acid-extractable fractions of $\mathrm{Cd}$ and Te did cluster by the type of coating with respect to the metal accumulation in the earthworms (Fig. 2). However, we do not interpret that as a coating-effect per se; but simply as a consequence of the effect of the coating on the dissolution of metal from the materials (Fig. S1). This 'coating-mediated effect' on the extractability of $\mathrm{Cd}$ and $\mathrm{Te}$ in the soil from the CdTe QD exposures showed that more Cd was extractable from $\mathrm{NH}_{4}{ }^{+}$-coated QDs compared to the others (Fig. 2). In theory, the chemical bond anchoring the 
coating (i.e., the surface ligand) to the core could add a mechanical stress to the metal

733

734

735

736

737

738

739

740

741

742

743

744

745

746

747

748

749

750

751

752

753

754

755

756

757

758

759

760

761

762

763

764

765

atoms on the exterior of the core to promote dissolution [ligand-promoted dissolution, (Louie et al., 2016)]. The exact mechanisms involved in this phenomena remain to be elucidated, but for example, the repulsion of ligands of the same charge might stiffen the coating to add mechanical stress to the anchoring point on the core; hence the coatings designed with surface charge tend to have more water- or acid-extractable $\mathrm{Cd}$ in the soil (Fig. 2). Or it may relate to lipid solubility, with the PEG coating forming a barrier to slow the dissolution of solutes.

Regardless of the mechanism(s), this coating-mediated effect on the dissolution (Fig. S1), and extractable metal fractions in the soil (Fig. 1), was not observable in the mean values for total metal accumulation of $\mathrm{Cd}$ or $\mathrm{Te}$ in the earthworms (Fig. 3). For example, the extractable Cd in soil from the $\mathrm{CdTe}-\mathrm{NH}_{4}{ }^{+} \mathrm{QDs}$ was relatively high (Fig. 2), but this did not lead to the highest $\mathrm{Cd}$ accumulation in the earthworms (Fig. 3). In short, the running order of any coating-mediated effect on the physico-chemical properties of the QDs was not in the same order as the subsequent total metal accumulation in the earthworms. This was not resolved by normalising the total metal bioaccumulation in the earthworms against the measured total metal concentration in the soil (i.e., the transfer factor: the total metal concentration in the earthworm divided by that in the soil, data not shown). Therefore, while there are some coating-mediated effects on the accumulation of $\mathrm{Cd}$ and Te (Fig. 3), they are not explained by free metal ions released from the ENMs, although they are related to the total metal in the soil during the exposure. From the viewpoint of environmental protection, threshold levels for metals in soil have been suggested for dissolved metals on the basis of free ion activity (Lofts et al., 2004), and while ligand models have also been applied to ENMs in soil (Judy and Bertsch, 2014), the assumption that free metal ions lead to toxicity or accumulation is not proven for CdTe QDs here, and needs to be verified for many other ENMs in soil.

\subsection{Effect of soil ageing on metal accumulation}

Soil guidelines are not available for ENMs, and while the individual parameters in colloid theory such as soil pH and ionic strength have been considered (Cornelis et al., 2014), the sum effect of all the possible transformations of an ENM that constitute 'ageing' of the material in soil are not yet understood. In the present study, only the bulk material showed a soil ageing-dependent effect on total metal accumulation in 
the earthworms; with much more metal accumulated in the aged soil experiment (compare Fig 3A and 3B for $\mathrm{Cd}$ ). This occurred, despite the total concentration of $\mathrm{Cd}$ and $\mathrm{Te}$ in the soil being slightly lower in the aged compared to fresh soil experiments (Fig. 1); suggesting greater bioavailability and hazard of the CdTe bulk material over time in soil. It was not possible to determine the water- and acid-extractable metals in the aged soil at the start of the aged experiment, as this would have required destructive sampling and disturbance of the soil boxes. However, the slightly lower metal concentrations in the aged soil was somewhat expected, and likely due to previous metal uptake by the earthworms in the fresh soil study, and metal uptake by the plants that had subsequently grown in the exposure containers during soil ageing. Thus the incidental plant growth in the soil (Figs. S2 and S3), may have partly remediated the total metal in the soils. Notably, the ratio of $\mathrm{Cd}$ :Te in the tissue of earthworms exposed to the bulk material was different in the aged soil experiment compared to that in fresh soil; suggesting that the bulk material had at least partly dissolved, with then separate uptake mechanisms for $\mathrm{Cd}$ and Te by the earthworms (as discussed above). The bulk material had a maximum dissolution rate of $<0.1 \mu \mathrm{g}$ $\mathrm{h}^{-1}$ for Cd (Table 1), and even at the highest soil dose with around $800 \mathrm{mg} \mathrm{Cd} \mathrm{kg}^{-1}$ of soil (Fig.1), in a $250 \mathrm{~g}$ box of the soil ( $200 \mathrm{mg} \mathrm{Cd}$ in total), this would equate to a dissolution of $16.8 \mu \mathrm{g}$ of $\mathrm{Cd}$ per week, or about $403 \mu \mathrm{g}$ in six months. So, the material form would still remain in excess after six months of ageing, and ignoring transformation processes such as suphidation that might stabilise the materials (Lead et al., 2018). The mechanism causing this soil ageing-dependent change in metal accumulation by earthworms requires further investigation.

In contrast to the bulk material, for all the CdTe QDs exposures in aged soil, the accumulation of $\mathrm{Cd}$ was similar to that in the fresh soil study, although slightly higher (Fig. 3C). There was also little difference in Te accumulation from the aged compared to fresh soil study (compare Fig 3B and 3D) for the CdTe QDs. It is not clear why soil ageing failed to accelerate the metal accumulation in the earthworms, as it did for the bulk material. The CdTe QDs are smaller and with a faster dissolution rate than the bulk material (Fig. S1, Table 1), and so more uptake of free metal ions might be expected. But this was not the case, suggesting some other particle metric was controlling the bioavailability of the CdTe QDs. Apart from size, the other key difference was that CdTe QDs were all manufactured with a surface coating, when the bulk material was not. So a lack of effect of soil ageing on metal accumulation may be 
800

801

802

803

804

805

806

807

808

809

810

811

812

813

814

815

816

817

818

819

820

821

822

823

824

825

826

827

828

829

830

831

832

833

due to the presence of the coatings. It is possible that organic ligands in the soil, such as the polyanionic charges of humic and fulvic acids, could electrostatically attract the positive coating of the CdTe- $\mathrm{NH}_{4}{ }^{+}$QDs, repulsion in the case of $\mathrm{CdTe}-\mathrm{COOH}$ QDs, or show steric entanglement with the CdTe-PEG QDs. Similar ideas have been proposed for the behaviour of QDs in natural water (Rocha et al., 2017). However, such phenomena would demand a clear and consistent coating-effect, but this was not observed with different coating-mediated effects on bioaccumulation in the fresh compared to aged soil experiments, and with exposure dose within each experiment (Fig. 3). Regardless of the mechanisms, the bulk material presents a bioaccumulation concern with soil ageing that is greater than the nano forms.

\subsection{Effects on survival and body weight}

In the fresh soil experiment, the control earthworms survived, gained weight, and did not show any abnormalities, indicating that the animals were healthy. Furthermore, there were no effects on survival in any of CdTe treatments; and in the CdTe-bulk treatment the earthworms also gained weight (Table 2). However, despite good survival, the animals in the CdTe QD treatments lost biomass (Table 2). There was also a negative correlation between the metal concentrations in the tissue and biomass (Fig. S5). The loss of biomass was partly attributed to a lack of feeding coupled with some shedding of the posterior segments. There were no consistent effects of percentage change in body mass by the type of coating on the CdTe QDs in the fresh soil experiment; and by day 28 all the earthworms in the $2000 \mathrm{mg} \mathrm{kg}^{-1} \mathrm{CdTe}$ QD treatments had lost around $50 \%$ of their body mass (Table 2 ). The latter suggests the earthworms at the higher doses were just below the threshold for mortality. Indeed, the shedding of posterior segments has been interpreted as a survival strategy (Sims and Gerard, 1985) and possibly an 'excretion' mechanism for metals in earthworms. The survival of the earthworms at the nominal 50 and $500 \mathrm{mg} \mathrm{kg}^{-1}$ CdTe QD concentrations in the fresh soil experiment was expected with respect to Cd toxicity, as earthworms are known to tolerate very high concentrations of dissolved Cd [28 day mortality LC $_{50}=588 \mathrm{mg} \mathrm{Cd} \mathrm{kg}{ }^{-1} \mathrm{dw}$, (Van Gestel et al., 1991)], which are partly chelated by metallothionein in the tissue (Stürzenbaum et al., 2001). Furthermore, the extractable $\mathrm{Cd}$ from the fresh soil experiment in most of the QD exposures was far less than the expected lethal concentration of dissolved $\mathrm{Cd}$, except in the nominal $2000 \mathrm{mg} \mathrm{CdTe} \mathrm{kg}^{-1} \mathrm{dw}$ CdTe- $\mathrm{NH}_{4}{ }^{+}$QD exposures. In earthworms, a critical body 
residue (CBR) of around $642 \mathrm{mg} \mathrm{Cd} \mathrm{kg}^{-1} \mathrm{dw}$ is suggested to cause $50 \%$ mortality (Conder and Lanno, 2000). This concentration of Cd was generally exceeded in earthworms exposed to the highest concentrations of CdTe QDs in the fresh (and aged) soil experiments (Fig. 3). Again, supporting the notion that the worms were close to the threshold for mortality at the highest exposure concentration. The absence of effects of the CdTe bulk material on growth and survival (Table 2), and the relatively modest $\mathrm{Cd}$ accumulation in those earthworms (Fig. 3), suggests the bulk material is much less hazardous than the nano forms in fresh soil.

In the aged soil experiment, like in the fresh soil study, the control earthworms survived and were healthy without a statistically significant loss of body mass. Similar to the fresh soil experiment, survival was also not affected by the CdTe-bulk exposures. However, unlike the situation in fresh soil, the nominal $2000 \mathrm{mg} \mathrm{CdTe} \mathrm{kg}$ ${ }^{1} \mathrm{dw}$ test concentration of the CdTe bulk material caused a reduction in biomass (Table 2). Notably, this was accompanied by a much higher total $\mathrm{Cd}$ concentration in those earthworms in the aged soil compared to fresh soil (Fig. 3). Together, this suggests that the bulk material becomes more hazardous with soil ageing because the $\mathrm{Cd}$ in the material becomes partly dissolved (discussed above) and therefore bioavailable for uptake.

In contrast to the fresh soil experiment, exposure to CdTe QDs in aged soil caused considerable mortality, even at the nominal concentration of $50 \mathrm{mg} \mathrm{kg}^{-1} \mathrm{dw}$ of CdTe QDs (Table 2). The CdTe QDs were, therefore, much more toxic after ageing of the soil. In addition, a coating-mediated effect on survival was also apparent in the aged soil experiment, with the toxicity ranking $\mathrm{CdTe}-\mathrm{PEG}<\mathrm{CdTe}-\mathrm{NH}_{4}{ }^{+}<\mathrm{CdTe}-\mathrm{COOH}$ QDs at the highest exposure concentration (Table 2). In a study using the same coatings on CuO ENMs at a concentration of $1000 \mathrm{mg} \mathrm{Cu} \mathrm{kg}^{-1}$, the $\mathrm{NH}_{4}{ }^{+}$-coated $\mathrm{CuO}$ ENMs were also acutely toxic following a period of ageing, however, $\mathrm{COOH}$-coated CuO ENMs were not (Tatsi et al., 2018). This implies that, while coating-mediated effects can occur, the precise ranking of the effect also depends on the type of metal core in the ENM. This might be expected, because the stability constants of metals with organic ligands vary according to the charge density of the metal and the type of ligand (Albert, 1950). However, stability constants are not yet available for metals in the solid or crystalline state as found in nanomaterials with ligands of different chain lengths or terminal residues. 

changes of body mass, with generally greater loss of body mass than that observed in the fresh soil experiment (Table 2). A coating-mediated effect on growth was also apparent, with the most prominent effects in the $\mathrm{NH}_{4}{ }^{+}$- and $\mathrm{COOH}-\mathrm{CdTe}$ QD exposures (Table 2). The same ammonium coating also significantly reduced earthworm biomass in exposures to $1000 \mathrm{mg} \mathrm{Cu} \mathrm{kg}^{-1} \mathrm{dw}$ as $\mathrm{CuO}-\mathrm{NH}_{4}{ }^{+}$(Tatsi et al., 2018). Changes in the appearance and feeding behaviour of the worms were also evident at lower concentrations in the aged soil experiment, and consistent with the notion that the aged soil was more hazardous to the health of the earthworms.

\subsection{Effects on reproduction}

Reproduction is regarded as the most sensitive endpoint for metal exposure of earthworms. The control earthworms produced the expected number of juveniles in both, fresh and aged soil experiments, meeting the validity criteria of the OECD TG 222 (OECD, 2004). In the fresh soil experiment, the number of juveniles produced was not affected in the CdTe-bulk exposures, while in the CdTe QD exposures the number of juveniles decreased as the exposure concentration elevated (Table 2). A coatingmediated effect was evident, with the $\mathrm{EC}_{50}$ values in the order: $\mathrm{CdTe}-\mathrm{COOH}<\mathrm{CdTe}$ $\mathrm{NH}_{4}{ }^{+}<$CdTe-PEG (Table 2); suggesting the PEG-coated material was the least hazardous with respect to juvenile production. If the measured concentration of total $\mathrm{Cd}$ in the exposure soils is considered in the fresh soil experiment (ranging from $~ 22$ to $780 \mathrm{mg} \mathrm{Cd} \mathrm{kg}^{-1} \mathrm{dw}$, Fig. 1), the $\mathrm{EC}_{50}$ values of between 65-108 (Table 3) are broadly comparable to the 56 day $\mathrm{EC}_{50}$ for cocoon production of $46.3 \mathrm{mg} \mathrm{Cd} \mathrm{kg}^{-1} \mathrm{dw}$ in earthworms exposed to 0-300 $\mathrm{mg} \mathrm{Cd} \mathrm{kg}^{-1}$ soil (Spurgeon et al., 1994). This suggests the reproductive toxicity of the CdTe QDs in the fresh soil study could mostly be explained by $\mathrm{Cd}$ exposure, and this was corroborated by a strong negative correlation of juvenile production with the tissue $\mathrm{Cd}$ concentration, rather than tissue $\mathrm{Te}$ concentration, in the adult worms (Fig. S5). The decrease in reproductive success is also consistent with bioenergetic theory, where the adult earthworms showing the least growth (biomass) are expected to invest less energy in reproduction. Lower adult biomass has been shown to be related to lower reproduction in regulatory tests (OECD, 2004). Crucially, the juvenile earthworms also showed a decrease in biomass, and this followed the same overall pattern as the effects on reproduction in the adults (Table 3), suggesting the exposures also impaired off-spring quality. There are few 
901

902

903

904

905

906

907

908

909

910

911

912

913

914

915

916

917

918

919

920

921

922

923

924

925

926

927

928

929

930

931

932

933

reports of juvenile production from adult earthworms exposed to ENMs, but like the present study, $\mathrm{TiO}_{2}$ ENMs also decrease juvenile production in earthworms (Schlich et al., 2012).

In the aged soil experiment, the control earthworms produced more juveniles than in the fresh soil study (Table 3). This is likely due to the higher organic matter (i.e., plant roots) in the aged soil that is known to encourage earthworms to produce more offspring (Lahive et al., 2017). Unlike the fresh soil experiment, in aged soil, the CdTe bulk material inhibited juvenile production to the extent that no juveniles were produced at the highest exposure concentration (Table 3 ) and the $\mathrm{Cd}$ concentration in the adult earthworms strongly correlated with this reproductive failure (Fig. S5); again suggesting that mobilisation of $\mathrm{Cd}$ from the bulk material during soil ageing caused the toxicity. Furthermore, the reproductive toxicity of the CdTe QDs also increased in the aged soil experiment, but the difference between the coated QDs was less pronounced, although CdTe- $\mathrm{NH}_{4}{ }^{+}$QDs remained most hazardous (Table 3). The further reduction in reproduction in the aged soil experiment may be explained by the higher accumulation of $\mathrm{Cd}$ and $\mathrm{Te}$ in the earthworms (Fig. 3), which was also associated with lower biomass in the adult worms. So bioenergetically, like the fresh soil experiment, poor growth or health in the adults likely gave rise to fewer offspring.

\subsection{Effects on ion regulation}

Cadmium is known to cause ion regulatory disturbances in organisms (Stürzenbaum et al., 2004), therefore, the sodium pump activity was assessed. In the fresh soil study, earthworms in the controls sustained sodium pump activity (Fig. 4), as well as an overall concentration of $\mathrm{Na}^{+}$and $\mathrm{K}^{+}$(Table S2), as expected in the earthworms (Tatsi et al., 2018). The sodium pump activity was inhibited the most in the CdTe-bulk treatment and at the highest exposure concentration (Fig. 4). However, exposure to CdTe QDs in fresh soil also inhibited the sodium pump. Of the ENMs, the CdTe-PEG and $-\mathrm{NH}_{4}{ }^{+}$QDs were most potent in inhibiting the sodium pump activity (Fig. 4). In the nominal 500 and $2000 \mathrm{mg} \mathrm{CdTe} \mathrm{kg}^{-1} \mathrm{dw}$ exposures to CdTe- $\mathrm{NH}_{4}{ }^{+}$, tissue $\mathrm{K}^{+}$concentrations also decreased (Table S2), being consistent with inhibition of the sodium pump. There appears to be no other reports of the effects of CdTe QDs on osmoregulation in earthworms, and whether the sodium pump inhibition is caused by $\mathrm{Cd}$ alone, Te alone, or both, requires further investigation. 

Of these, there were some transient changes in $\mathrm{Zn}$ and $\mathrm{Fe}$ in the fresh soil experiment, but no clear dose effect, and no effects in the aged soil experiment. However, copper and manganese showed some interesting changes. The control earthworms showed the expected tissue Cu [8 - $10 \mathrm{mg} \mathrm{Cu} \mathrm{kg}^{-1} \mathrm{dw}$, (Streit, 1984; Tatsi et al., 2018)] and

939 Mn concentrations [43-54 $\mathrm{mg} \mathrm{Mn} \mathrm{kg}^{-1} \mathrm{dw}$ this study; $~ 50 \mathrm{mg} \mathrm{Mn} \mathrm{kg}^{-1} \mathrm{dw}$ in L. rubellus, 940 (Oste et al., 2001)]. The manganese concentration was reduced by almost 3 times in 941 the CdTe QD ENM exposures, for both the fresh and aged soil experiments, and also 942 for the bulk material exposures in the aged soil experiment (Table S2). The mechanistic cause of this $\mathrm{Mn}$ depletion in earthworms requires further investigation,

944 but $\mathrm{Cd}$-dependent inhibition of $\mathrm{Mn}$ uptake has been observed in fibroblast cell lines 945 (Yanagiya et al., 2000), possibly mediated by competition for uptake on divalent metal 946 ion transporter 1 (DMT1). Copper depletion was correlated with higher tissue Cd (Fig. 947 S5) in the CdTe-COOH exposures (500 and $2000 \mathrm{mg} \mathrm{CdTe} \mathrm{kg}^{-1} \mathrm{dw}$ ) and $\mathrm{CdTe}^{-\mathrm{NH}_{4}}{ }^{+}$ 948 exposure (500 mg CdTe kg-1 dw), and with the effects evident in both fresh and aged 949 soil experiments (Table S2). The loss of $\mathrm{Cu}$ (and Mn) might arise from a passive non950 specific electrolyte leak associated with tissue injury since other essential elements such as $\mathrm{K}, \mathrm{Ca}$ and $\mathrm{Mg}$ concentrations were significantly reduced compared to the 952 controls in the fresh soil (Table S2). However, this seems unlikely in the absence of 953 glutathione depletion (Fig. 4, no clear difference in total GHS pool were observed) and 954 the major electrolytes were undisturbed in the tissues in the aged soil experiment, 955 despite some tissue Cu depletion. Cu is a regulated metal in earthworms (Streit, 1984), 956 and it could simply be that $\mathrm{Cd}^{2+}$ is displacing $\mathrm{Cu}$ from ligands such as metallothionein 957 and glutathione in the tissue. Regardless of the mechanism, both $\mathrm{Cu}$ and $\mathrm{Mn}$ were 958 decreased in the tissue of earthworms from both the fresh and aged soil studies, and 959 with the same coated QDs, $\mathrm{COOH}$ and $\mathrm{NH}_{4}{ }^{+}$, being most potent for this effect (Table 960 S2). 


\subsection{Plant growth during soil ageing}

It was not the purpose of this study to assess the effects of CdTe materials on plant growth, but some incidental observation on plant coverage were made (Figs. S2 and S3). Similar to the earthworms, the QDs were more toxic to the plants and moss than the bulk material and there was a coating-mediated effect on plant coverage; with the $\mathrm{CdTe}-\mathrm{COOH}$ and $\mathrm{CdTe}-\mathrm{NH}_{4}{ }^{+}$QDs abolishing growth at the highest concentrations. In hydroponic media, plant cuttings from poplar trees exposed to $\mathrm{Cd} /$ Se-containing QDs with cationic or anionic surface coatings, showed apparently faster uptake of the cationic material; possible because it is electrostatically attracted to the negatively charged surface of the plant (Wang et al., 2014). The effects of organic coatings on CdS QDs have also been recently explored on soya bean seedling (Majumdar et al., 2019); with the amino acid profiles in the plants clustering by material, although the coating-effect was not consistent across a range of endpoints. Currently, there are too many data gaps to offer a clear mechanistic understanding of ENM effects on plants (Schwab et al., 2016), and any apparent coating-mediated effects on vascular plants requires further investigation.

The earthworms were inevitably feeding on the plant root material in the aged soil experiment, and so this might be both a source of nutrition and metal exposure from any nanomaterial on the surface of the roots. However, the plant growth or the presence of ENMs in soil might be expected to alter the soil properties. Indeed, QDs may change the porosity and the transport of solutes in soil with subsequent effects on the plants and invertebrates (Al-Salim et al., 2011). In the present study, the moisture content and $\mathrm{pH}$ was adjusted in the soils, but changes in the soil structure with soil ageing cannot be excluded as a factor in the metal accumulation of the earthworms in the aged soil experiment.

\subsection{Conclusions and regulatory perspective}

Taken together, the results here compared to the known toxicity of $\mathrm{Cd}$ in earthworms indicate the CdTe QD ENMs are of similar acute and reproductive toxicity to earthworms. When comparing the bulk vs nano-scale CdTe QDs, there may be a size-effect, since the nano-scale CdTe QDs were generally more toxic than the CdTebulk counterpart. There was also a coating-mediated effect, where the most toxic QD was generally the $\mathrm{CdTe}-\mathrm{COOH}$ material, closely followed by $\mathrm{CdTe}-\mathrm{NH}_{4}{ }^{+}$QDs. However, this was not a direct coating effect per se, but likely a consequence of other 
subtle changes in the physico-chemical properties of the material during manufacture, such as the differences in the ratio of the apparent metal concentrations in each material. In keeping with this notion, the toxic effects seen in the study were related to accumulation of $\mathrm{Cd}$ in earthworm tissues, however, this was not easily explained by the measured dissolution rate of $\mathrm{Cd}$ from the QDs (Table 1 ) or the extractability of $\mathrm{Cd}$ from the soils (Fig. 2). The existing environmental risk assessment for dissolved $\mathrm{Cd}$ is likely to be protective of both bulk and nano forms of CdTe materials, although the type of coating and any subsequent changes in particle properties associated with adding the coating, should be considered in the environmental risk analysis. Crucially, the toxicity of the CdTe QDs increased after a period of ageing of the soil, suggesting that the hazard should be monitored, and any environmental risk assessment revisited in order to maintain protection of the soil ecosystem. Finally, it would be important to ascertain the mechanisms of toxicity for Te, since it is widely used in a QD form and currently there are no environmental risk assessments which give guidance on safe levels of Te in soils.

\section{Conflicts of interest}

The authors alone are responsible for the content and writing of the paper. The authors report no conflicts of interest.

\section{Acknowledgements}

The research was funded as part of the EU FP-7 NANOSOLUTIONS Project, grant agreement no. 309329. Dr Alexei Antipov (PlasmaChem GmbH, www. plasmachem.com) provided the coated-ENMs and their associated core. The authors thank Dr Claus Svendsen and Dr Elma Lahive at the CEH (Wallingford, UK) for providing advice on earthworm culturing and the experimental deigns. $\mathrm{Dr}$ Joanne Vassallo and Dr Benjamin Shaw are acknowledged for assisting with the experimental set up and design, respectively. Dr Andrew Fisher is acknowledged for assistance with metal analyses. Also Alex Besinis, Nathaniel Clark and Shannon Rees for dissolution measurements.

\section{References}

Al-Salim, N., et al., 2011. Quantum dot transport in soil, plants, and insects. Science of the Total Environment. 409, 3237-3248. 
Albert, A., 1950. Quantitative studies on the avidity of naturally occurring substances for trace metals. 1. Amino-acids having only two ionizing groups. Biochemical Journal. 47, 531-538.

Arnold, R., Hodson, M., 2007. Effect of time and mode of depuration on tissue copper concentrations of the earthworms Eisenia andrei, Lumbricus rubellus and Lumbricus terrestris. Environmental Pollution. 148, 21-30.

Ba, L. A., et al., 2010. Tellurium: an element with great biological potency and potential. Organic \& Biomolecular Chemistry. 8, 4203-4216.

Belzile, N., Chen, Y.-W., 2015. Tellurium in the environment: A critical review focused on natural waters, soils, sediments and airborne particles. Applied Geochemistry. 63, 83-92.

Besinis, A., et al., 2014. The antibacterial effects of silver, titanium dioxide and silica dioxide nanoparticles compared to the dental disinfectant chlorhexidine on Streptococcus mutans using a suite of bioassays. Nanotoxicology. 8, 1-16.

Brown, B. E., 1982. The form and function of metal-containing 'granules'in invertebrate tissues. Biological Reviews. 57, 621-667.

Buffet, P.-E., et al., 2014. Biochemical and behavioural responses of the marine polychaete Hediste diversicolor to cadmium sulfide quantum dots (CdS QDs): waterborne and dietary exposure. Chemosphere. 100, 63-70.

Chlopecka, A., et al., 1996. Forms of cadmium, lead, and zinc in contaminated soils from southwest Poland. Journal of Environmental Quality. 25, 69-79.

Conder, J. M., Lanno, R. P., 2000. Evaluation of surrogate measures of cadmium, lead, and zinc bioavailability to Eisenia fetida. Chemosphere. 41, 1659-1668.

Cornelis, G., et al., 2014. Fate and bioavailability of engineered nanoparticles in soils: a review. Critical Reviews in Environmental Science and Technology. 44, 2720-2764.

Domingos, R. F., et al., 2011. Bioaccumulation and effects of CdTe/CdS quantum dots on Chlamydomonas reinhardtii-nanoparticles or the free ions? Environmental Science \& Technology. 45, 7664-7669.

Gardea-Torresdey, J. L., et al., 2014. Trophic transfer, transformation, and impact of engineered nanomaterials in terrestrial environments. Environmental Science \& Technology. 48, 2526-2540.

González, V., et al., 2013. Assessing the impact of organic and inorganic amendments on the toxicity and bioavailability of a metal-contaminated soil to the earthworm Eisenia andrei. Environmental Science and Pollution Research. 20, 8162-8171.

Handy, R. D., et al., 2012. Practical considerations for conducting ecotoxicity test methods with manufactured nanomaterials: what have we learnt so far? Ecotoxicology. 21, 933-972.

Hardman, R., 2005. A toxicologic review of quantum dots: toxicity depends on physicochemical and environmental factors. Environmental Health Perspectives. 114, 165-172.

Hopkin, S. P., 1989. Ecophysiology of metals in terrestrial invertebrates. Elsevier Applied Science Publishers, Barking, UK.

Judy, J. D., Bertsch, P. M., Bioavailability, toxicity, and fate of manufactured nanomaterials in terrestrial ecosystems. In: D. Sparks, (Ed.), Advances in Agronomy. Elsevier, Amsterdam, 2014, pp. 1-64.

Kairdolf, B. A., et al., 2013. Semiconductor quantum dots for bioimaging and biodiagnostic applications. Annual Review of Analytical Chemistry. 6, 143162. 
Keshavarz Jamshidian, M., et al., 2017. Toxicokinetics and time-variable toxicity of cadmium in Oppia nitens Koch (Acari: Oribatida). Environmental Toxicology and Chemistry. 36, 408-413.

Lahive, E., et al., 2017. Sewage sludge treated with metal nanomaterials inhibits earthworm reproduction more strongly than sludge treated with metal metals in bulk/salt forms. Environmental Science: Nano. 4, 78-88.

Lead, J. R., et al., 2018. Nanomaterials in the environment: behavior, fate, bioavailability, and effects-an updated review. Environmental Toxicology and Chemistry. 37, 2029-2063.

Lofts, S., et al., 2004. Deriving soil critical limits for $\mathrm{Cu}, \mathrm{Zn}, \mathrm{Cd}$, and $\mathrm{Pb}$ : a method based on free ion concentrations. Environmental Science \& Technology. 38, 3623-3631.

Louie, S. M., et al., 2016. Critical review: impacts of macromolecular coatings on critical physicochemical processes controlling environmental fate of nanomaterials. Environmental Science: Nano. 3, 283-310.

Lowry, G. V., et al., 2012. Transformations of nanomaterials in the environment. Environmental Science \& Technology 46, 6893-6899.

Luo, C., et al., 2011. Heavy metal contamination in soils and vegetables near an ewaste processing site, south China. Journal of Hazardous Materials. 186, 481-490.

Majumdar, S., et al., 2019. Surface coating determines the response of soybean plants to cadmium sulfide quantum dots. Nanolmpact. 14, 100151.

McCormick, S. D., 1993. Methods for nonlethal gill biopsy and measurement of $\mathrm{Na}^{+}$, $\mathrm{K}^{+}$-ATPase activity. Canadian Journal of Fisheries and Aquatic Sciences. 50, 656-658.

Navarro, E., et al., 2008. Environmental behavior and ecotoxicity of engineered nanoparticles to algae, plants, and fungi. Ecotoxicology. 17, 372-386.

OECD, OECD guidelines for testing of chemicals: Earthworm reproduction test (Eisenia fetidal Eisenia andrei). TG 222. Paris, France, 2004.

Oste, L. A., et al., 2001. Cadmium uptake by earthworms as related to the availability in the soil and the intestine. Environmental Toxicology and Chemistry. 20, 1785-1791.

Owens, C., Belcher, R., 1965. A colorimetric micro-method for the determination of glutathione. Biochemical Journal. 94, 705.

$\mathrm{Qu}, \mathrm{Y}$., et al., 2011. Full assessment of fate and physiological behavior of quantum dots utilizing Caenorhabditis elegans as a model organism. Nano Letters. 11, 3174-3183.

Ramadan, S. E., et al., 1989. Incorporation of tellurium into amino acids and proteins in a tellurium-tolerant fungi. Biological Trace Element Research. 20, 225.

Rocha, T. L., et al., 2017. Environmental behaviour and ecotoxicity of quantum dots at various trophic levels: A review. Environment International. 98, 1-17.

Schlich, K., et al., 2012. Effect of $\mathrm{TiO}_{2}$ nanoparticles in the earthworm reproduction test. Environmental Sciences Europe. 24, 5.

Schwab, F., et al., 2016. Barriers, pathways and processes for uptake, translocation and accumulation of nanomaterials in plants-Critical review. Nanotoxicology. 10, 257-278.

Sims, R. W., Gerard, B. M., 1985. Earthworms: keys and notes for the identification and study of the species. The Pitman Press, London. 
Sinha, P., et al., 2012. Fate and transport evaluation of potential leaching risks from cadmium telluride photovoltaics. Environmental Toxicology and Chemistry. 31, 1670-1675.

Spurgeon, D., et al., 1994. Effects of cadmium, copper, lead and zinc on growth, reproduction and survival of the earthworm Eisenia fetida (Savigny): assessing the environmental impact of point-source metal contamination in terrestrial ecosystems. Environmental Pollution. 84, 123-130.

Srivastava, S., et al., 2016. Curcumin and $\beta$-caryophellene attenuate cadmium quantum dots induced oxidative stress and lethality in Caenorhabditis elegans model system. Environmental Toxicology and Pharmacology. 42, 55-62.

Stewart, D. T., et al., 2013. Quantum dots exhibit less bioaccumulation than free cadmium and selenium in the earthworm Eisenia andrei. Environmental Toxicology and Chemistry. 32, 1288-1294.

Streit, B., 1984. Effects of high copper concentrations on soil invertebrates (earthworms and oribatid mites). Oecologia. 64, 381-388.

Stürzenbaum, S., et al., 2013. Biosynthesis of luminescent quantum dots in an earthworm. Nature Nanotechnology. 8, 57.

Stürzenbaum, S. R., et al., 2004. Cadmium detoxification in earthworms: from genes to cells. Environmental Science \& Technology. 38, 6283-6289.

Stürzenbaum, S. R., et al., 2001. Metal ion trafficking in earthworms Identification of a cadmium-specific metallothionein. Journal of Biological Chemistry. 276, 34013-34018.

Tatsi, K., et al., 2018. Copper accumulation and toxicity in earthworms exposed to $\mathrm{CuO}$ nanomaterials: Effects of particle coating and soil ageing. Ecotoxicology and Environmental Safety. 166, 462-473.

Van Gestel, C., et al., 1991. Influence of cadmium, copper, and pentachlorophenol on growth and sexual development of Eisenia andrei (Oligochaeta; Annelida). Biology and Fertility of Soils. 12, 117-121.

Vassallo, J., et al., 2018. The minimum inhibitory concentration (MIC) assay with Escherichia coli: An early tier in the environmental hazard assessment of nanomaterials? Ecotoxicology and Environmental Safety. 162, 633-646.

Wang, J., et al., 2014. Uptake, translocation, and transformation of quantum dots with cationic versus anionic coatings by Populus deltoides $\times$ nigra cuttings. Environmental Science \& Technology. 48, 6754-6762.

Wu, T., et al., 2015. MPA-capped CdTe quantum dots exposure causes neurotoxic effects in nematode Caenorhabditis elegans by affecting the transporters and receptors of glutamate, serotonin and dopamine at the genetic level, or by increasing ROS, or both. Nanoscale. 7, 20460-20473.

Yanagiya, T., et al., 2000. Suppression of a high-affinity transport system for manganese in cadmium-resistant metallothionein-null cells. Journal of Pharmacology and Experimental Therapeutics. 292, 1080-1086. 
1171 Table 1 Characterisation of the CdTe QDs used in the experiments.

\begin{tabular}{|c|c|c|c|c|c|c|}
\hline \multirow[t]{2}{*}{ QD variant } & \multirow[t]{2}{*}{${ }^{1}$ Manufacturer's Information } & \multirow[t]{2}{*}{$\begin{array}{l}{ }^{2} \text { Estimated primary particle } \\
\text { size, diameter }(\mathrm{nm})\end{array}$} & \multirow[t]{2}{*}{$\begin{array}{l}{ }^{3} \mathrm{NTA} \text {, hydrodynamic } \\
\text { diameter }(\mathrm{nm})\end{array}$} & \multirow{2}{*}{$\begin{array}{l}{ }^{4} \mathrm{TGA}, \\
\text { (\% weight } \\
\text { loss) }\end{array}$} & \multicolumn{2}{|c|}{$\begin{array}{l}{ }^{5} \text { Maximum rate of dissolution } \\
\text { in Milli } Q \text { water }\left(\mu \mathrm{g} \mathrm{h}^{-1}\right)\end{array}$} \\
\hline & & & & & $\mathrm{Cd}$ & $\mathrm{Te}$ \\
\hline CdTe-Bulk & $\begin{array}{l}\text { CASRN 1306-25-8 } \\
\text { (Sigma-Aldrich } \\
256544 \text { ), Lot No. } \\
\text { MKBK6448V, } \geq 99.99 \% \text { purity } \\
\text { trace metal basis }\end{array}$ & $<250 \mu \mathrm{m}$ & $172 \pm 28$ & NA & $<0.1$ & 0.2 \\
\hline $\begin{array}{l}\text { CdTe- } \\
\text { Polyethylene } \\
\text { Glycol }\end{array}$ & $\begin{array}{l}\text { Lot No.YF140402, 99\% purity, } \\
\text { size } 3-5 \mathrm{~nm} \text {. }\end{array}$ & $<4$ & $156 \pm 72$ & $50.4 \pm 8.3$ & 6.4 & 2.3 \\
\hline CdTe- Carboxylate & $\begin{array}{l}\text { Lot No.YF140402, 99\% purity, } \\
\text { size } 3-5 \mathrm{~nm} \text {. }\end{array}$ & $<4$ & $84 \pm 58$ & $23.4 \pm 4.2$ & 3.9 & 1.3 \\
\hline CdTe- Ammonium & $\begin{array}{l}\text { Lot No. YF140402, 99\% } \\
\text { purity, size 3-5 nm. }\end{array}$ & $<4$ & $75 \pm 50$ & $8.8 \pm 0.5$ & 29.0 & 14.9 \\
\hline
\end{tabular}

$1172{ }_{1}^{1}$ Supplied as dry powders, spherical particles for the Nanosolutions project via Alexei Antipov, PlasmaChem GmbH.

11732 It was not possible to detect the QDs using electron microscopy, therefore an estimate is given (Denmark Technical University)

$1174{ }^{3}$ NTA- Nanoparticle Tracking Analysis using NanoSight using $100 \mathrm{mg} \mathrm{CdTe}^{-1}$ ENM stocks in Milli-Q water at University of

1175 Plymouth. Data are mean \pm S.D. $n=3$ samples

11764 TGA - thermogravimetric analysis. Triplicate measurements (technical replicates) made on the same batch of the dry powders

1177 using a TGA 4000 (Perkin Elmer) under an $\mathrm{N}_{2}$ flow of $20 \mathrm{ml} \mathrm{min}^{-1}$ from $25^{\circ} \mathrm{C}$ to $995^{\circ} \mathrm{C}$ at a heating rate of $10^{\circ} \mathrm{C} \mathrm{min}^{-1}$ at the

1178 University of Manchester. Note, this measurement would include the pyrolysis of the organic coating and any other combustible

1179 (presumably organic) impurities in/on the materials.

11805 Maximum slope from rectangular hyperbola function of curve fitting used to estimate the maximum rate of dissolution of Cd and Te

1181 from dialysis experiments conducted at University of Plymouth, conducted exactly according to (Besinis et al., 2014). 
1182 NA - not applicable to the test item.

1183

1184

1185 
1186 Table 2 Survival and biomass of earthworms following 14 and 28 days exposure to CdTe QDs in fresh or 28 days in aged soils.

\begin{tabular}{|c|c|c|c|c|c|c|c|c|c|c|c|}
\hline \multirow{2}{*}{\multicolumn{2}{|c|}{$\begin{array}{l}\text { Soil [CdTe], nominal } \\
\text { mg CdTe kg-1 dw }\end{array}$}} & \multirow{2}{*}{$\begin{array}{l}\text { Control } \\
\text { Survival }\end{array}$} & \multirow[b]{2}{*}{ Biomass } & \multicolumn{2}{|l|}{ CdTe-bulk } & \multicolumn{2}{|c|}{ CdTe-PEG } & \multicolumn{2}{|c|}{$\mathrm{CdTe}-\mathrm{COOH}$} & \multicolumn{2}{|c|}{ CdTe- $\mathrm{NH}_{4}{ }^{+}$} \\
\hline & & & & Survival & Biomass & Survival & Biomass & Survival & Biomass & Survival & Biomass \\
\hline \multicolumn{12}{|c|}{ Fresh soil, day 14} \\
\hline \multirow[t]{2}{*}{50} & Total & 5 & $2.1 \pm 0.1^{\mathrm{a}}$ & 5 & $2 \pm 0.1^{a}$ & 5 & $2.3 \pm 0.1^{a}$ & 5 & $1.8 \pm 0.1^{\mathrm{a}}$ & 5 & $2.1 \pm 0.1^{\mathrm{a}}$ \\
\hline & $\%$ & 100 & $\uparrow 15.9 \pm 6.4$ & 100 & $\uparrow 3.0 \pm 3.6$ & 100 & $\uparrow 16.9 \pm 3$ & 100 & $\uparrow 22.7 \pm 10.4$ & 100 & $\uparrow 25.7 \pm 0.9$ \\
\hline \multirow[t]{2}{*}{500} & Total & & & 5 & $2.03 \pm 0.1^{a}$ & 5 & $1.9 \pm 0.06^{a}$ & $4.8 \pm 0.2$ & $2 \pm 0.1^{a}$ & 5 & $1.9 \pm 0.1^{a}$ \\
\hline & $\%$ & & & 100 & $\uparrow 12.9 \pm 2.6$ & 100 & $\uparrow 10 \pm 3.9$ & $95 \pm 5$ & $\uparrow 11.9 \pm 2.4$ & 100 & $\downarrow 4.2 \pm 1.5$ \\
\hline 2000 & $\begin{array}{l}\text { Total } \\
\%\end{array}$ & & & $\begin{array}{l}5 \\
100\end{array}$ & $\begin{array}{l}1.9 \pm 0.06^{a} \\
\uparrow 4.2 \pm 1.8\end{array}$ & $\begin{array}{l}5 \\
100\end{array}$ & $\begin{array}{l}1.3 \pm 0.1^{b} \\
\downarrow 24.9 \pm 3.9\end{array}$ & $\begin{array}{l}5 \\
100\end{array}$ & $\begin{array}{l}1.4 \pm 0.1^{\mathrm{b}} \\
\downarrow 28 \pm 2.4^{*}\end{array}$ & $\begin{array}{l}4.8 \pm 0.2 \\
95 \pm 5\end{array}$ & $\begin{array}{l}1.23 \pm 0.1^{b} \\
\downarrow 36.6 \pm 4.3\end{array}$ \\
\hline \multicolumn{12}{|c|}{ Fresh soil, day 28} \\
\hline \multirow[t]{2}{*}{50} & Total & 5 & $2.2 \pm 0.1^{\mathrm{a}}$ & $4.8 \pm 0.2$ & $1.9 \pm 0.1^{a}$ & 5 & $2.4 \pm 0.1^{a}$ & 5 & $2.1 \pm 0.1^{a}$ & 5 & $2.2 \pm 0.1^{a}$ \\
\hline & $\%$ & 100 & $\uparrow 19.9 \pm 5.1$ & $95 \pm 5$ & $\downarrow 0.4 \pm 4.6$ & 100 & ${ }^{\uparrow} 21.7 \pm 6.1$ & 100 & ${ }^{\uparrow} 28 \pm 11.9$ & 100 & $\uparrow 31.6 \pm 3.1$ \\
\hline \multirow[t]{2}{*}{500} & Total & & & 5 & $2.2 \pm 0.1^{a}$ & $4.8 \pm 0.2$ & $1.9 \pm 0.1^{b \#}$ & 5 & $1.9 \pm 0.1^{b \#}$ & 5 & $1.66 \pm 0.1^{b}$ \\
\hline & $\%$ & & & 100 & $\uparrow 22.7 \pm 3.7$ & $95 \pm 5$ & $\uparrow 8.1 \pm 3.3$ & 100 & ${ }^{\uparrow} 8.7 \pm 4.2$ & 100 & $\downarrow 15 \pm 1.9$ \\
\hline \multirow[t]{2}{*}{2000} & Total & & & $4.8 \pm 0.2$ & $2.14 \pm 0.1^{\text {a \# }}$ & 5 & $0.91 \pm 0.1^{\mathrm{c \#}}$ & 5 & $1.05 \pm 0.1^{\mathrm{c \#}}$ & $4.8+0.2$ & $0.95 \pm 0.1^{c \#}$ \\
\hline & $\%$ & & & $95 \pm 5$ & $\uparrow 10.9 \pm 3.6$ & 100 & $\checkmark 49.4 \pm 3.8$ & 100 & $\downarrow 46.6 \pm 2.9$ & $95 \pm 5$ & $\downarrow 50.9 \pm 4.4$ \\
\hline \multicolumn{12}{|c|}{ Aged soil, day 28} \\
\hline \multirow[t]{2}{*}{50} & Total & $5 \pm 0.3$ & $1.7 \pm 0.1^{1 \text { * }}$ & 5 & $1.8 \pm 0.1^{\mathrm{a}}$ & $4 \pm 0.5$ & $1.4 \pm 0.1^{1 \text { * }}$ & 5 & $1.7 \pm 0.1^{1^{\star}}$ & 5 & $1.8 \pm 0.1^{1 *}$ \\
\hline & $\%$ & $95 \pm 5$ & $\downarrow 8.1 \pm 5.6$ & 100 & $\downarrow 4.1 \pm 7.7$ & $85 \pm 10$ & $\downarrow 22.4 \pm 8$ & 100 & $\downarrow 17.2 \pm 5.1$ & 100 & $\sqrt{9.4 \pm 3.6}$ \\
\hline \multirow[t]{2}{*}{500} & Total & & & 5 & $1.7 \pm 0.1^{\mathrm{a}}$ & $4.8 \pm 0.2$ & $1.8 \pm 0.2^{a *}$ & $5 \pm 0.3$ & $1.3 \pm 0.1^{b *}$ & $4 \pm 0.4$ & $1.2 \pm 0.1^{b *}$ \\
\hline & $\%$ & & & 100 & $\downarrow 2.9 \pm 2.7$ & $95 \pm 5$ & $\downarrow 17 \pm 9.2$ & $90 \pm 5$ & $\downarrow 28.2 \pm 4.9$ & $80 \pm 8$ & $\downarrow 33.7 \pm 3.7$ \\
\hline \multirow[t]{2}{*}{2000} & Total & & & $4.8 \pm 0.2$ & $1.3 \pm 0.1^{b}$ & $4 \pm 0.5$ * & $0.7 \pm 0.1^{c *}$ & $2.8 \pm 0.2$ * & $0.6 \pm 0.1^{c *}$ & $3 \pm 1.1$ & $0.8 \pm 0.2^{c}$ \\
\hline & $\%$ & & & $95 \pm 5$ & $\downarrow 31.4 \pm 8.6$ & $75 \pm 10$ & $\downarrow 59.6 \pm 7.4$ & $55 \pm 5$ & $\downarrow 64.7 \pm 5.8$ & $60 \pm 25$ & $\downarrow 56.8 \pm 7.2$ \\
\hline
\end{tabular}

1187 Survival is reported as the total number of earthworms per treatment (total) and as percent survival (\%). Similarly, the biomass is 1188 reported as the total biomass of surviving earthworms per treatment (wet weight, $\mathrm{g}$ ) and the percentage weight increase or 1189 decrease relative to the animals at the start of the experiment. Data presented as mean \pm SEM ( $n=4$ boxes of worms per 1190 treatment). Treatments that do not share a letter are statistically significantly different within an experiment at the specified time- 
1191 point and the hash $\left(^{\#}\right)$ denotes statistically significant differences between treatments on day 14 and $28(P<0.05$ repeated

1192 measures ANOVA for biomass data or Kruskal-Wallis for survival data). Asterisk $\left(^{*}\right)$ denotes statistically significant differences

1193 between treatments in the fresh and aged soil experiments.

1194 Day 0 mean wet weight was $1.86 \pm 0.02 \mathrm{~g}$ (mean \pm SEM, for a subsample of 5 of the initial earthworms, $n=52$ treatments) in fresh

1195 soil experiment.

1196 Day 0 mean wet weight of $1.89 \pm 0.03 \mathrm{~g}$ of per exposure replicate (mean \pm SEM, for a subsample of 5 of the initial earthworms, $n=$ 119752 treatments) in the aged soil experiment.

$1198 \uparrow$ Increase in wet weight relative to day 0

$1199 \downarrow$ Decrease in wet weight relative to day 0

1200

1201

1202

1203

1204

1205

1206

1207

1208 
1209 Table 3 Total number of juveniles produced and their total fresh weight in the fresh soil experiment and total number of juveniles 1210 produced in the aged soil experiment. The $\mathrm{EC}_{50}$ and estimated NOEC values in each treatment in the fresh and aged soil

1211 experiment.

\begin{tabular}{|c|c|c|c|c|c|c|c|c|c|c|}
\hline \multirow{2}{*}{$\begin{array}{c}\text { Soil } \\
{[\mathrm{CdTe}]} \\
\text { nominal } \\
\text { mg CdTe } \\
\mathrm{kg}^{-1} \mathrm{dw}\end{array}$} & \multicolumn{2}{|c|}{ Control } & \multicolumn{2}{|c|}{ CdTe-bulk } & \multicolumn{2}{|c|}{ CdTe-PEG } & \multicolumn{2}{|c|}{$\mathrm{CdTe}-\mathrm{COOH}$} & \multicolumn{2}{|c|}{ CdTe-NH${ }_{4}^{+}$} \\
\hline & $\begin{array}{c}\text { No of } \\
\text { juveniles }\end{array}$ & $\begin{array}{l}\text { Biomass } \\
\text { (g) }\end{array}$ & $\begin{array}{c}\text { No of } \\
\text { juveniles }\end{array}$ & $\begin{array}{l}\text { Biomass } \\
\text { (g) }\end{array}$ & $\begin{array}{c}\text { No of } \\
\text { juveniles }\end{array}$ & $\begin{array}{l}\text { Biomass } \\
\text { (g) }\end{array}$ & $\begin{array}{c}\text { No of } \\
\text { juveniles }\end{array}$ & $\begin{array}{l}\text { Biomass } \\
\text { (g) }\end{array}$ & $\begin{array}{c}\text { No of } \\
\text { juveniles }\end{array}$ & $\begin{array}{l}\text { Biomass } \\
\text { (g) }\end{array}$ \\
\hline \multicolumn{11}{|l|}{ Fresh soil } \\
\hline 50 & $25 \pm 5^{a}$ & $\begin{array}{c}0.370 \pm \\
0.06^{\mathrm{a}}\end{array}$ & $22 \pm 6^{a}$ & $\begin{array}{c}0.222 \pm \\
0.09^{\mathrm{a}}\end{array}$ & $18 \pm 1^{a}$ & $\begin{array}{c}0.0267 \pm \\
0.057^{\mathrm{a}}\end{array}$ & $18.25 \pm 4^{a}$ & $\begin{array}{c}0.220 \pm \\
0.08^{\mathrm{a}}\end{array}$ & $20 \pm 3^{a}$ & $0.307 \pm 0.084^{a}$ \\
\hline 500 & & & $18 \pm 2^{a}$ & $\begin{array}{c}0.250 \pm \\
0.061^{\mathrm{a}}\end{array}$ & $3 \pm 2^{b}$ & $\begin{array}{c}0.033 \pm \\
0.026^{\mathrm{b}}\end{array}$ & $3 \pm 1^{b}$ & $\begin{array}{l}0.005 \pm \\
0.003^{b}\end{array}$ & $1 \pm 0^{\mathrm{b}}$ & $0.006^{b}$ \\
\hline 2000 & & & $19 \pm 3^{a}$ & $\begin{array}{l}0.142 \pm \\
0.024^{\mathrm{b}}\end{array}$ & $0^{\mathrm{b}}$ & ND & $0^{\mathrm{b}}$ & ND & $0^{\mathrm{b}}$ & ND \\
\hline $\mathrm{EC}_{50}$ & & & NA & & $\begin{array}{c}108(72- \\
165)\end{array}$ & & $\begin{array}{c}65(30- \\
142)\end{array}$ & & $96(20-610)$ & \\
\hline NOEC & & & $>2000$ & & 50 & & 50 & & 50 & \\
\hline \multicolumn{11}{|l|}{ Aged soil } \\
\hline 50 & $41 \pm 5^{a *}$ & & $30 \pm 3^{a}$ & & $30 \pm 2^{a *}$ & & $32 \pm 2^{a *}$ & & $35 \pm 4^{a *}$ & \\
\hline 500 & & & $10 \pm 1^{b *}$ & & $2 \pm 1^{c}$ & & $0^{c^{*}}$ & & $0^{c}$ & \\
\hline 2000 & & & $0^{c *}$ & & $0^{c}$ & & $0^{c}$ & & $0^{c}$ & \\
\hline $\mathrm{EC}_{50}$ & & & $\begin{array}{c}165(109- \\
243)\end{array}$ & & $88(62-127)$ & & 78 (NA) & & $63(\mathrm{NA})$ & \\
\hline NOEC & & & 50 & & 50 & & 50 & & 50 & \\
\hline
\end{tabular}

1212 Data presented as mean \pm SEM $(n=4)$. Different letters denote statistically significant differences between treatments within an

1213 experiment $\left(P<0.05\right.$, ANOVA). Asterisk $\left({ }^{*}\right)$ denote statistically significant differences between the treatment between fresh and

1214 aged soil experiment $(P<0.05$ T-test, unpaired). The biomass is reported as the total biomass all the juveniles produced treatment 
1215 (wet weight, g). EC50 values for $50 \%$ reduction in reproduction after 4 weeks of exposure in fresh and aged soils with CdTe QDs 1216 are presented with $95 \%$ confidence intervals in the brackets, the concentration response curves are presented in Fig. S4. NA - not 1217 possible to calculate $\mathrm{EC}_{50}$ due to no effect; not possible to calculate confidence intervals due to high effect. Note, because of the 1218 difficulty in removing juveniles from amongst the plant roots that had grown in the soil during ageing, we were not confident in 1219 removing all of the small juveniles intact in order to report an accurate total biomass for juveniles in the aged experiment. 

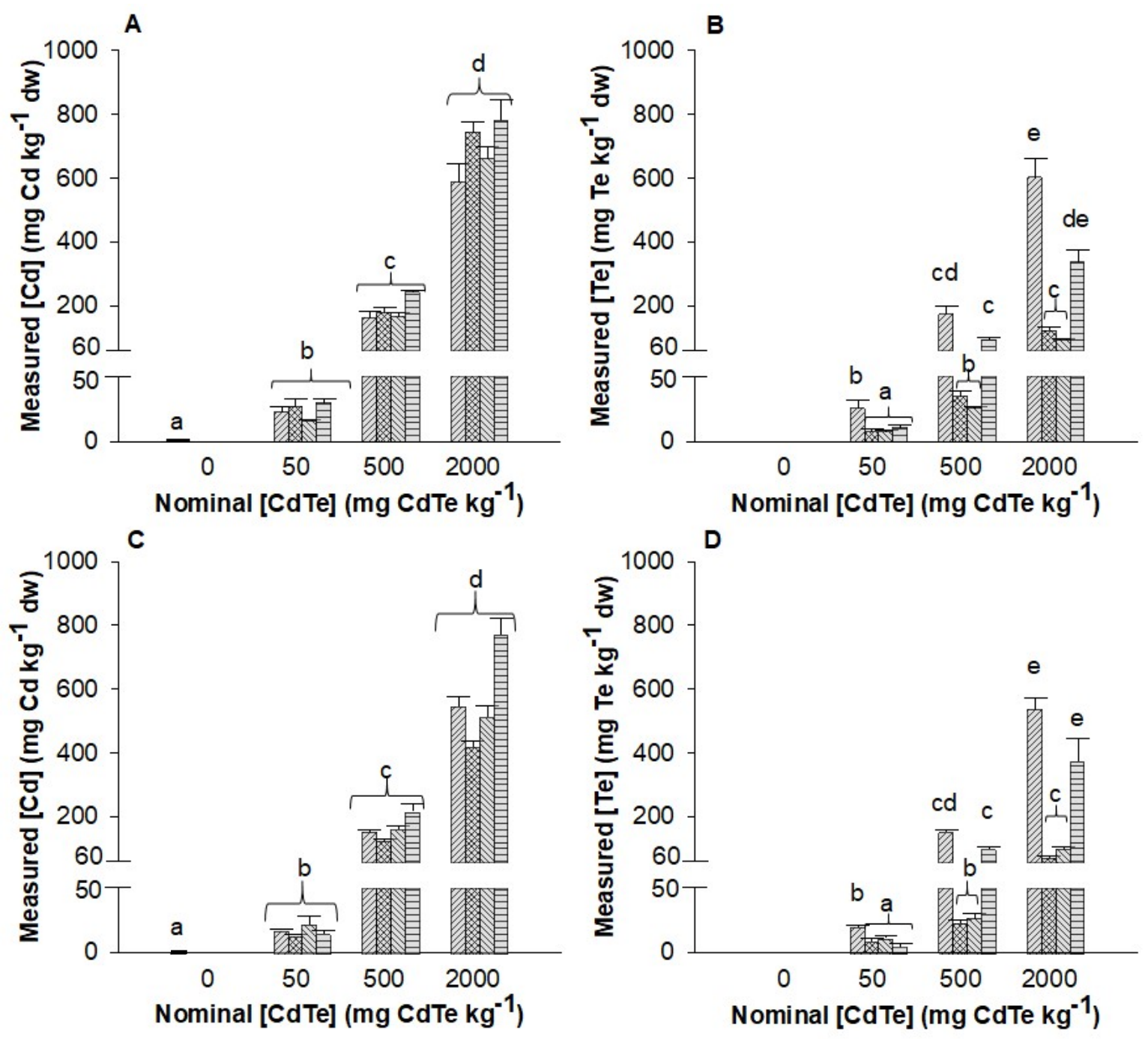

1221

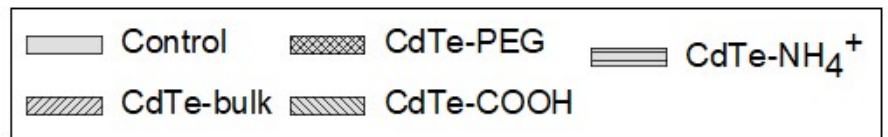

1222 Fig. 1 Total measured $\mathrm{Cd}(\mathrm{A}, \mathrm{C})$ and $\mathrm{Te}(\mathrm{B}, \mathrm{D})$ concentration in soil ( $\left.\mathrm{mg} \mathrm{kg}^{-1} \mathrm{dw}\right)$ at 1223 the beginning of the fresh (upper panels) and aged (lower panels) soil experiment.

1224 Data expressed as mean \pm SEM $(n=8)$. Different letters show statistically significant 1225 differences between treatments within test concentration $(P<0.05$, ANOVA). There 1226 were no statistically significant differences between treatments within a dose in the 1227 fresh compared to aged exposures $(P>0.05, t$-test, unpaired). 


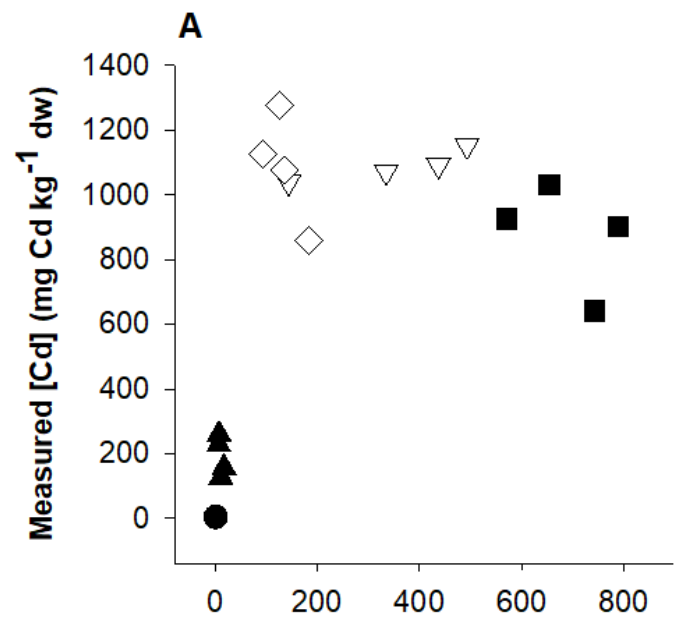

$0.1 \mathrm{M} \mathrm{HCl}$ extractable [Cd] (mg Cd kg-1 $\mathrm{dw})$

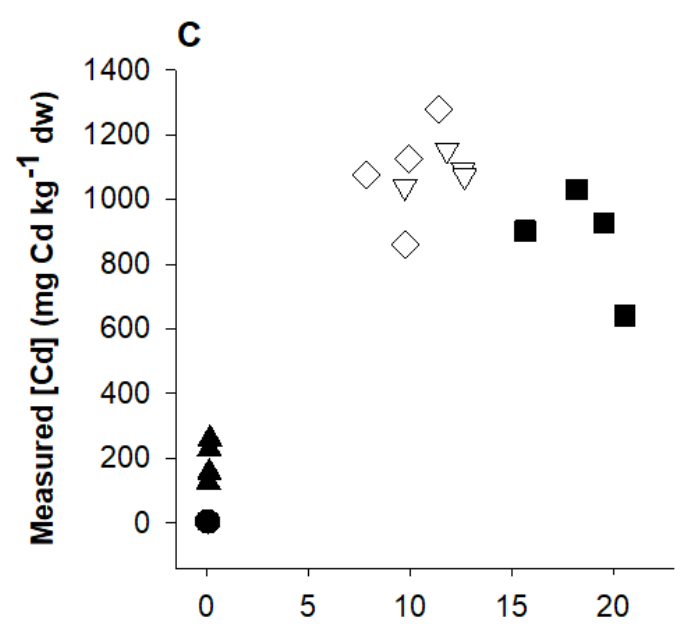

Water extractable $[\mathrm{Cd}]\left(\mathrm{mg} \mathrm{Cd} \mathrm{kg}^{-1} \mathrm{dw}\right)$

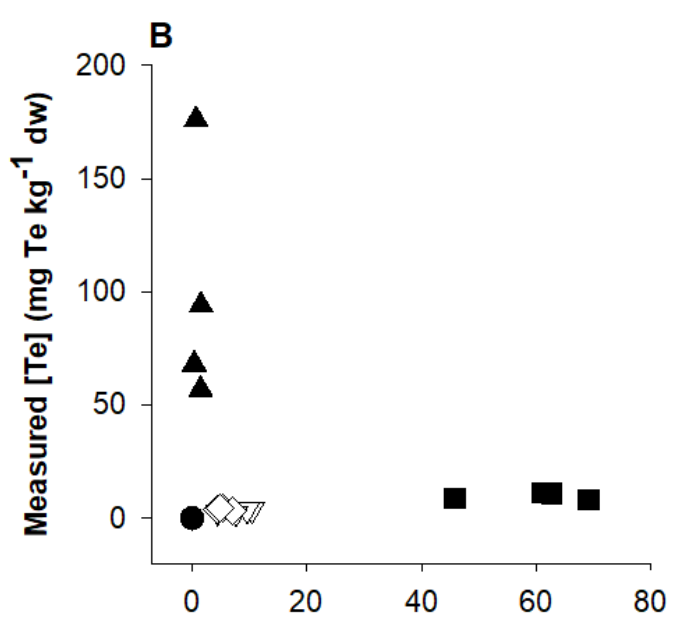

$0.1 \mathrm{M} \mathrm{HCl}$ extractable $[\mathrm{Te}]\left(\mathrm{mg} \mathrm{Te} \mathrm{kg}{ }^{-1} \mathrm{dw}\right)$

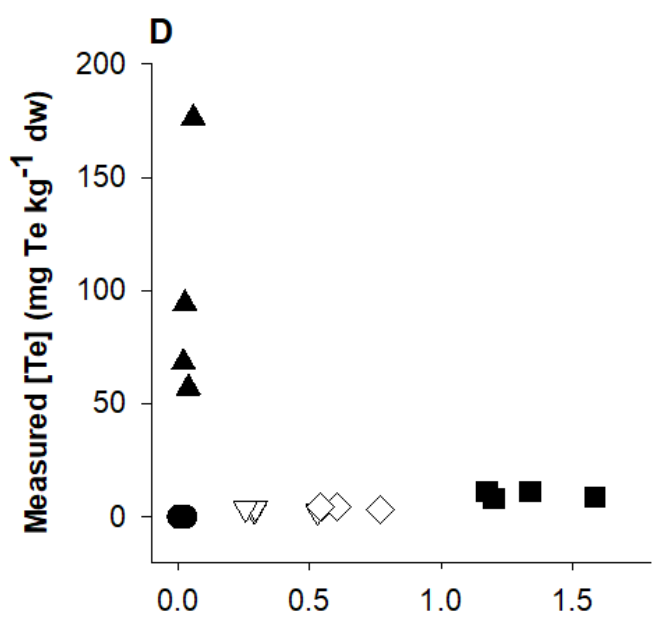

Water extractable $[\mathrm{Te}]\left(\mathrm{mg} \mathrm{Te}_{\mathrm{kg}}{ }^{-1} \mathrm{dw}\right)$

\begin{tabular}{|lllllllll}
\hline - Control $\triangle$ & CdTe-bulk & $\nabla$ & $\mathrm{CdTe}-\mathrm{COOH}$ & $\diamond$ & $\mathrm{CdTe}-\mathrm{PEG}$ & $\boldsymbol{C}$ & $\mathrm{CdTe}_{\mathrm{NH}}{ }^{+}$ \\
\hline
\end{tabular}

1229 Fig. 2 Relationship between the concentration of acid extractable Cd or Te (A or B) 1230 and water extractable $\mathrm{Cd}$ or Te (C or D) and measured total Cd or Te concentration 1231 in earthworm tissue in the fresh soil experiment. Data shown for nominal $2000 \mathrm{mg}$

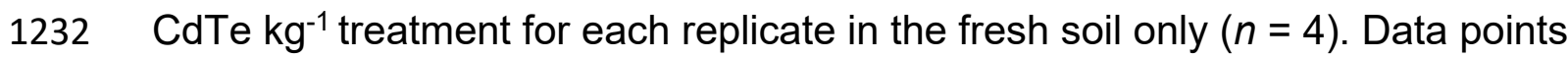
1233 represent mean values ( $n=2$ for soil samples, $n=4$ for earthworm) for each 1234 replicate $(n=4)$, error bars excluded for clarity. 

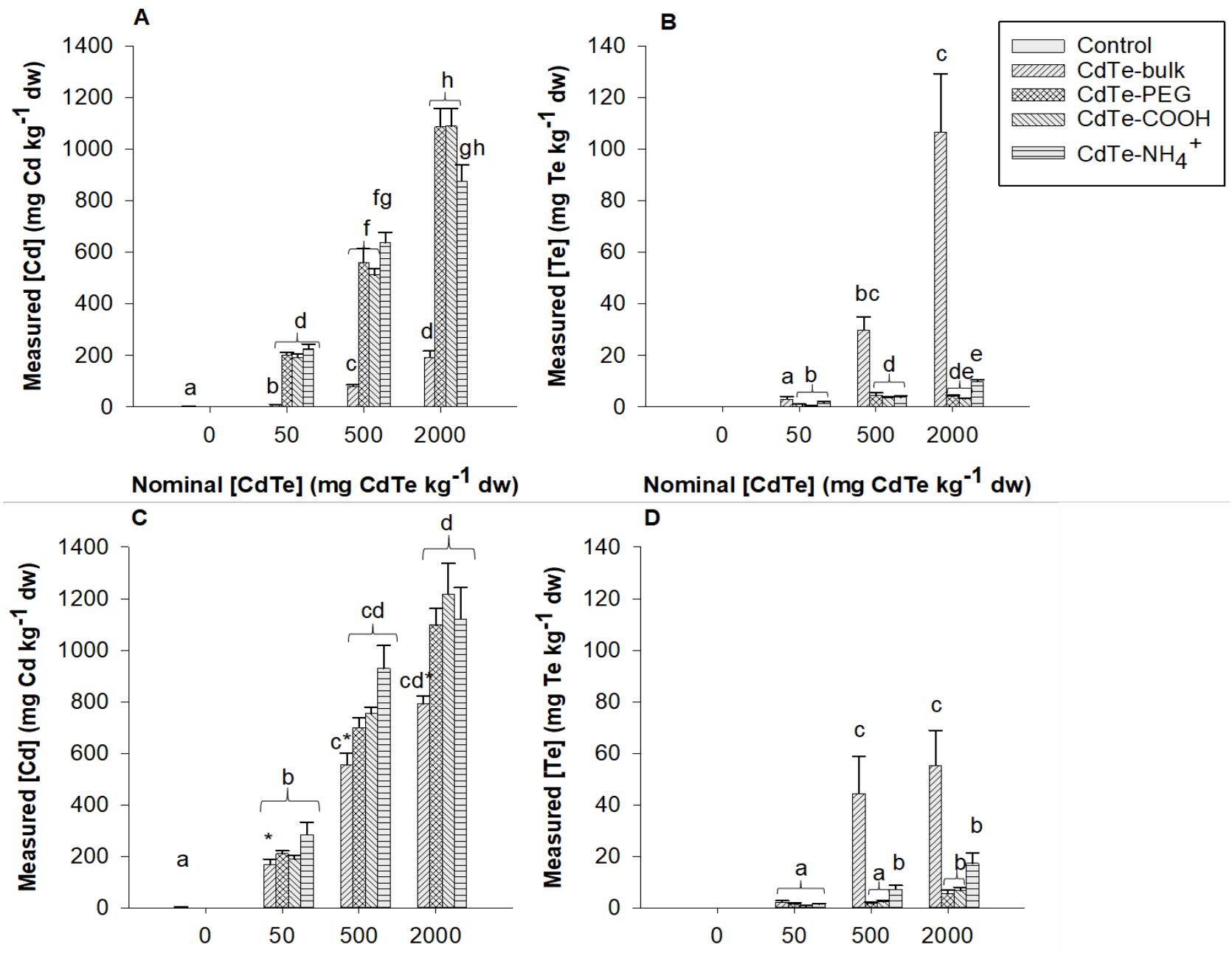

Nominal [CdTe] (mg CdTe $\left.\mathrm{kg}^{-1} \mathrm{dw}\right)$

1236 Fig. 3 Total measured $\mathrm{Cd}(\mathrm{A}, \mathrm{C})$ and Te (B, D) concentration in earthworm tissue

1237 ( $\mathrm{mg} \mathrm{kg}^{-1} \mathrm{dw}$ ) on day 28 of the fresh (upper panels) and aged (lower panels) soil

1238 experiments. Different letters denote the statistically significant differences between

1239 treatments within test concentration $(P<0.05$, ANOVA). Asterisks denote statistically

1240 significant differences between treatments within a dose in the fresh compared to

1241 aged exposures $(P<0.05, t$-test, unpaired $)$. 

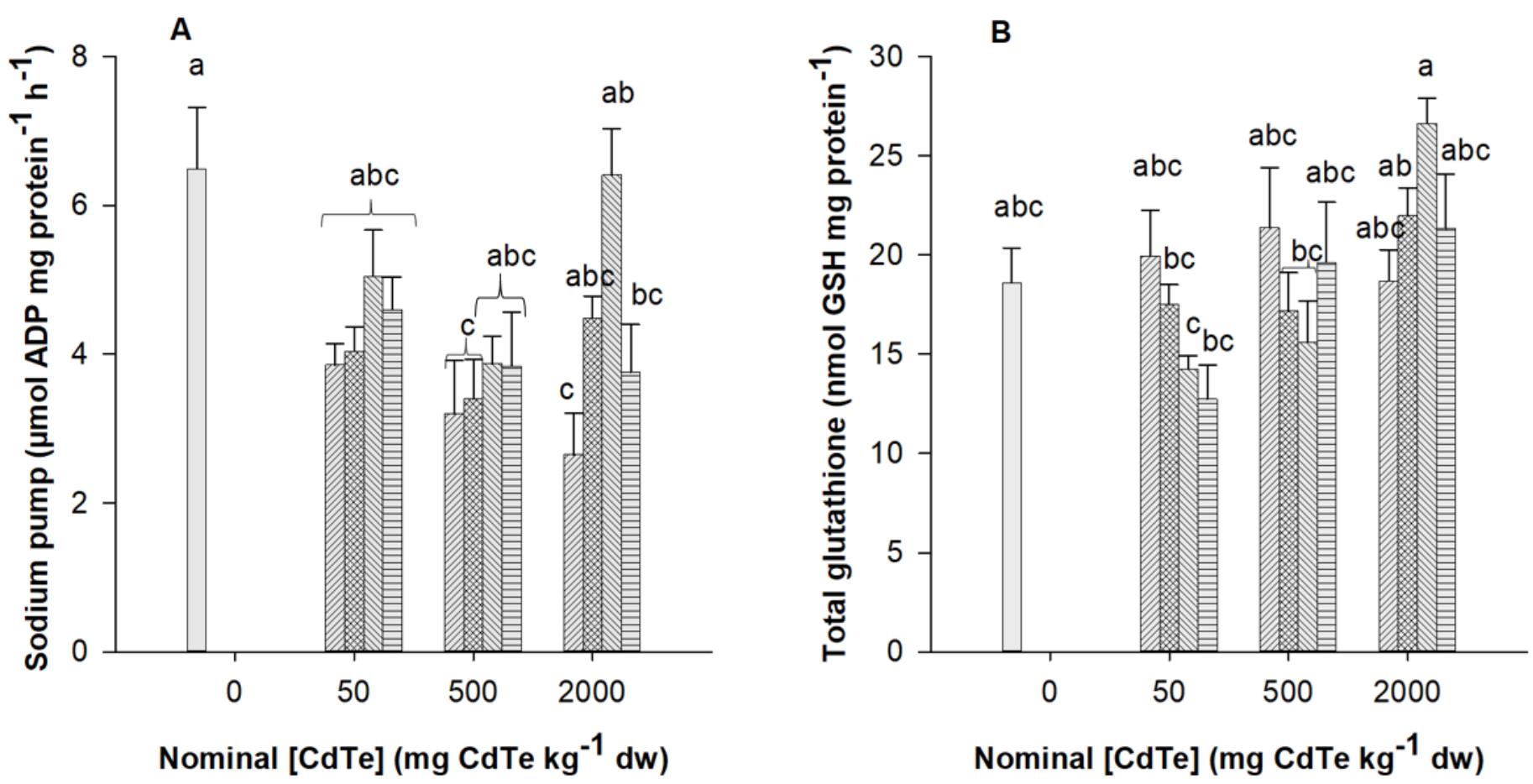

Fig. 4 (A) $\mathrm{Na}^{+} / \mathrm{K}^{+}$-ATPase activity (sodium pump) expressed as ADP $\mu$ mol released per mg protein per hour in earthworms in the fresh soil experiment. $(B)$ Total glutathione nmol per mg protein in the earthworms in the fresh soil experiment. Data is presented as mean \pm SEM $(n=8)$. Different letters denote statistically significant differences between treatments $(P<0.05$, ANOVA). 